\title{
Structural and Vibrational studies (FT-IR, FT-Raman) of Voglibose using DFT calculation
}

\author{
R. Solaichamy ${ }^{a}$, J. Karpagam ${ }^{a *}$ \\ aDepartment of Physics (Engg.), Annamalai University, Annamalainagar-608 002, Tamil Nadu, \\ India. \\ ${ }^{*}$ Corresponding author \\ E-mail address: karaviram@rediffmail.com
}

Keywords: FT-IR; FT-Raman; NBO; UV-Vis; NMR; TED.

\begin{abstract}
In the present study, we report on the Molecular structure and infrared (IR) and FTRaman studies of Voglibose (VGB) as well as by calculations based on the density functional theory (DFT) approach; utilizing B3LYP/6-31G(d,p) basis set. The targeted interpretation of the vibrational spectra intended to the basis of calculated potential energy distribution matrix (PED) utilizing VEDA4 program. Stability of the molecule arising from hyperconjugative interactions and charge delocalization was studied using natural bond orbital (NBO) analysis. The results show that change in electron density in the $\sigma^{*}$ and $\pi^{*}$ antibonding orbitals and $\mathrm{E}^{2}$ energies confirm the occurrence of intramolecular charge transfer within the molecule. The UV-Visible and NMR spectral analysis were reported by using TD-DFT and gauge GIAO approach respectively and their chemical shifts related to TMS were compared. The lowering of HOMO and LUMO energy gap appears to be the cause for its enhanced charge transfer interactions. Besides, molecular electrostatic potential (MEP) analysis was reported. Due to different potent biological properties, the molecular docking results are also reported.
\end{abstract}

\section{INTRODUCTION}

Voglibose is a new and potent in-hibitor of $\alpha$-glucosidases and is used for the treatment of diabetes mellitus. Voglibose is chemically known as 3,4-Dideoxy-4-[2-hydroxy-1-(hydroxyl methyl) ethyl]amino-2-c-(hydroxymethyl)-D-epinositol has attracted considerable interests due to its wide range of therapeutic and pharma-cological properties, including its excellent inhibitory activity against $\alpha$-glucosidase and its action against hyperglycemia and various disorders caused by hyper-glycemia [1]. Voglibose obtained from organic synthesis processes is similar to structurally related carbohydrates found naturally $[2,3]$ and has the empirical formula $\mathrm{C}_{10} \mathrm{H}_{21} \mathrm{NO}_{7}$. For the treatment of diabetes. It is specifically used for lowering postprandial blood glucose levels thereby reducing the risk of macrovascular complications.

Recently, Iwamoto et al reported [4] Efficacy and safety of vildagliptin and voglibose in Japanese patients with type 2 diabetes: a 12-week, randomized, double-blind, active-controlled study. Mallikarjuna Rao et al [1] presented RP-HPLC method development and validation for estimation of Voglibose in bulk and tablet dosage forms. Determination of voglibose in pharmaceutical formulations by high performance liquid chromatography using refractive index detection given by Karunanidhi Lakshmi et al [5]. Hong Zhang et al [2] reported ${ }^{1} \mathrm{H}$ and ${ }^{13} \mathrm{C}$ NMR analysis of Voglibose and its derivatives. A Comparative Study of Acarbose and Voglibose on Postprandial Hyperglycemia and serum lipids in Type 2 Diabetic patients reported by P. Revathi et al [6].

With the guide of above seen written works, it is clear that there is no quantum mechanical study on this VGB molecule which has propelled to do a definite quantum mechanical investigation for comprehension the vibrational modes, UV-Visible, chemical shifts, HOMO-LUMO, MEP. In this commitment, the structural and vibrational investigations of a basic VGB molecule was introduced and talked about. In the present work we want to focus on vibrational spectrum of the title compound inclusive its interpretation based on the theoretical spectrum calculated by means of 
density functional theory (DFT). The redistribution of electron density (ED) in various bonding, antibonding orbitals and $\mathrm{E}^{(2)}$ energies have been calculated by natural bond orbital (NBO) analysis to give clear evidence of stabilization originating from the hyperconjugation of various intramolecular interactions.

\section{MATERIALS AND METHODS}

\subsection{FT-IR, FT-Raman and UV-Vis analysis}

The compound Voglibose was purchased from Aldrich chemicals, USA and used as such to record the FT-IR and FT-Raman, UV spectra. Bruker IFS $66 \mathrm{~V}$ spectrometer was used to record the FT-IR spectrum by $\mathrm{KBr}$ pellet method on a equipped with a Globar source, $\mathrm{Ge} / \mathrm{KBr}$ beam splitter, and a TGS detector in the range of $4000-400 \mathrm{~cm}^{-1}$. The spectral resolution was $2 \mathrm{~cm}^{-1}$. The FTRaman spectrum was obtained on a Bruker RFS 100/s, Germany and the excitation of the spectrum is with the emission of Nd:YAG laser with a wavelength of $1064 \mathrm{~nm}$, maximal power $150 \mathrm{~mW}$. Cary 500 UV-VIS-NIR spectrometer was used to record the UV absorption spectra associated with Voglibose were examined with the range $200-800 \mathrm{~nm}$. The UV pattern is usually acknowledged from the $10^{-5}$ molar solution connected with VGB, dissolved with ethanol solvent.

\section{COMPUTATIONAL DETAILS}

Calculations of the title compound were carried out with the Gaussian 03W program [7] using B3LYP/6-31G(d,p) basis set to predict the molecular structure and vibrational wave numbers and a scaling factor of 0.9608 is used for obtaining a considerably better agreement with experimental data [8,9]. The assignments of the calculated wave numbers are aided by the animation option of the VEDA4 [10] program. The atomic charges, distribution of electron density (ED) in various bonding and antibonding orbitals and stabilization energies, $\mathrm{E}^{(2)}$ have been calculated by natural bond orbital (NBO) analysis were performed using NBO 3.1 program [11] as implemented in the Gaussian 03W [7] package at the DFT/B3LYP level of calculation. UV-Visible spectra, electronic transitions, vertical excitation energies and oscillator strengths were computed with the time-dependent DFT method with 6-31G(d,p) basis set in gas phase and using ethanol as solvent. The ${ }^{1} \mathrm{H}$ and ${ }^{13} \mathrm{C}$ NMR isotropic shielding were calculated with the GIAO method [12] using the optimized parameters obtained from B3LYP/6-31G(d,p) method.

\subsection{Prediction of Raman intensities}

The Raman activities $\left(\mathrm{S}_{\mathrm{Ra}}\right)$ calculated with Gaussian 03W program [7] converted to relative Raman intensities $\left(\mathrm{I}_{\mathrm{Ra}}\right)$ using the following relationship derived from the intensity theory of Raman scattering $[13,14]$

$$
I_{i}=\frac{f\left(v_{o}-v_{i}\right)^{4} S_{i}}{v_{i}\left[1-\exp \left(-h c v_{i} / k t\right)\right]}
$$

Where, $v_{0}$ is the laser exciting wavenumber in $\mathrm{cm}^{-1}$ (in this work, we have used the excitation wavenumber $v_{0}=9398.5 \mathrm{~cm}^{-1}$, which corresponds to the wavelength of $1064 \mathrm{~nm}$ of a Nd-YAG laser), $v_{i}$ the vibrational wavenumber of the $i^{\text {th }}$ normal mode $\left(\mathrm{cm}^{-1}\right)$ while $S_{i}$ is the Raman scattering activity of the normal mode $v_{i}[15]$.

\section{RESULTS AND DISCUSSIONS}

\subsection{Conformational stability}

In order to describe conformational flexibility of the title molecule, the energy profile as a function of N13-C15-C16-O17 torsion angle was achieved with B3LYP/6-31G(d,p) level of calculation as shown in Fig. 1. All the geometrical parameters were simultaneously relaxed during the calculations while the N13-C15-C16-O17 torsional angle was varied in steps of $10^{\circ}, 20^{\circ}, 30^{\circ} \ldots$ $360^{\circ}$. The energy values obtained from the scan output show that, the structure has a minimum energy (-974.609 Hartree), when the dihedral angle N13-C15-C16-O17 is $0^{\circ}$ or $360^{\circ}$ (global minimum) and -974.994 Hartree (local minimum) when the dihedral angle N13-C15-C16-O17 is 
$160^{\circ}$. Therefore, in the present work we have focused on the most stable form of VGB molecule to clarify molecular structure and assignments of vibrational spectra.

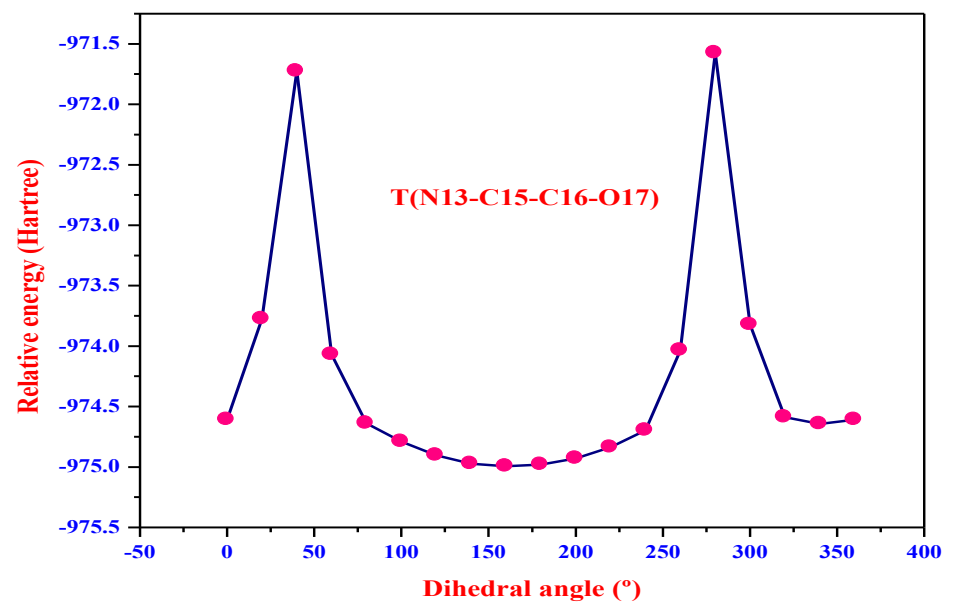

Fig. 1. Dihedral angle-relative energy curves of the Voglibose by B3LYP/6-31G (d,p) level of theory

\subsection{Molecular geometry}

The optimized geometrical parameters such as bond length, bond angles and dihedral angles calculated by B3LYP/6-31G(d,p) level of calculation using Gaussian $03 \mathrm{~W}$ program package. To the best of our knowledge, the experimental data on geometric structure of VGB is not available in the literature. Therefore, the theoretical results of VGB have been compared together with closely related molecule 1-Cyclohexylmethoxymethyl-5-[2-hydroxy-1-(hydroxymethyl) ethylamino] cyclohexane-1, 2, 3, 4-tetraol [16] as given in Table 1. The C-C bond length of the cyclohexane ring varies from $1.534 \AA-1.565 \AA$. Due to the $\mathrm{O}-\mathrm{H}$ group substitution on the $\mathrm{C} 1, \mathrm{C} 2, \mathrm{C} 3$ and $\mathrm{C} 4^{\text {th }}$ position of the cyclohexane ring, the $\mathrm{C}-\mathrm{C}$ bond lengths are not same for example $\mathrm{C} 1-\mathrm{C} 2=1.565 \AA$, $\mathrm{C} 1-\mathrm{C} 6=1.536 \AA, \mathrm{C} 2-\mathrm{C} 3=1.544 \AA, \mathrm{C} 3-\mathrm{C} 4=1.538 \AA$ calculated by DFT method. The $\mathrm{C}-\mathrm{O}$ bond length on the cyclohexane ring varies from $1.416 \AA-1.429 \AA$ by DFT method is good agreement with experimental value $1.429 \AA-1.439 \AA$. The N13-H32 bond length is $1019 \AA$ calculated by DFT method. N-C bond lengths are C5-N13=1.481 $\AA / 1.480 \AA$, N13-C15=1.480 $\AA / 1.467 \AA$ calculated by DFT/XRD respectively, this result shows good agreement between Theoretical and experimental values. The $\mathrm{C}-\mathrm{H}$ bond lengths of ethyl alcohol $\left(\mathrm{CH}_{2} \mathrm{OH}\right)$ group is $\mathrm{C} 11-\mathrm{H} 29=1.100 \AA$, $\mathrm{C} 11$ $\mathrm{H} 30=1.094 \AA$ and $\mathrm{C} 14-\mathrm{H} 33=1.092 \AA, \mathrm{C} 14-\mathrm{H} 34=1.096 \AA$ calculated by DFT method.

As shown in Fig. 2, the molecular structure of title compound contains one six-membered ring this ring (from $\mathrm{C}-1$ to $\mathrm{C}-6$ ) adopt chair conformations. The cyclohexane ring is disordered, with three of the $\mathrm{C}$ atoms distributed on two sites with approximately equal occupancy. In addition, one of the hydroxymethyl groups attached to $\mathrm{C} 1$ is disordered over the positions. The bond angle at point on the substitution is C2-C1-C6 $=110.9 \% 109.0^{\circ}$ calculated by DFT/XRD respectively. The unit -N13-C15-C16-O17- connected with $\mathrm{C} 5$ by the way of an equatorial bond, and the angles of N13-C5-H22 show $110.9^{\circ}$ (DFT), C6-C5-N13 show $112.0^{\circ}$ (DFT), $110.9^{\circ}$ (XRD) and C4-C5N13 show $106.2^{\circ}$ (DFT), $108.9^{\circ}$ (XRD). The N13-C15-C16 was like a bridge that aligned with cyclohexane ring and $\mathrm{CH}_{2} \mathrm{OH}$.

Dihedral angles of cyclohexane part are found as $\mathrm{C} 1-\mathrm{C} 2-\mathrm{C} 3-\mathrm{C} 4=-50.92^{\circ}, \mathrm{C} 2-\mathrm{C} 3-\mathrm{C} 4-$ $\mathrm{C} 5=53.78^{\circ}, \mathrm{C} 3-\mathrm{C} 4-\mathrm{C} 5-\mathrm{C} 6=-54.98^{\circ}$ and $\mathrm{C} 4-\mathrm{C} 5-\mathrm{C} 6-\mathrm{C} 1=54.89^{\circ}$. In case of twist form, the $\mathrm{N}$-atom with the attached carbon 5 was considered are twisted about N13-C5-C6-C1=173.04 ${ }^{\circ}$ and $\mathrm{C} 3-\mathrm{C} 4-$ $\mathrm{C} 5-\mathrm{N} 13=-176.63^{\circ}$. Meanwhile in the molecule, hydrogen bonded N13-H32...O10 appeared in the crystal with a bond length 2.803 (2) $\AA$ and bond angle $117.3^{\circ}$ [17]. From the theoretical values, we found the idea most of our optimized bond lengths are slightly larger than experimental values due 
to be able to fact that the theoretical calculations belong to be able to isolated molecules throughout gaseous phase as well as the experimental results belong for molecules in the solid state.

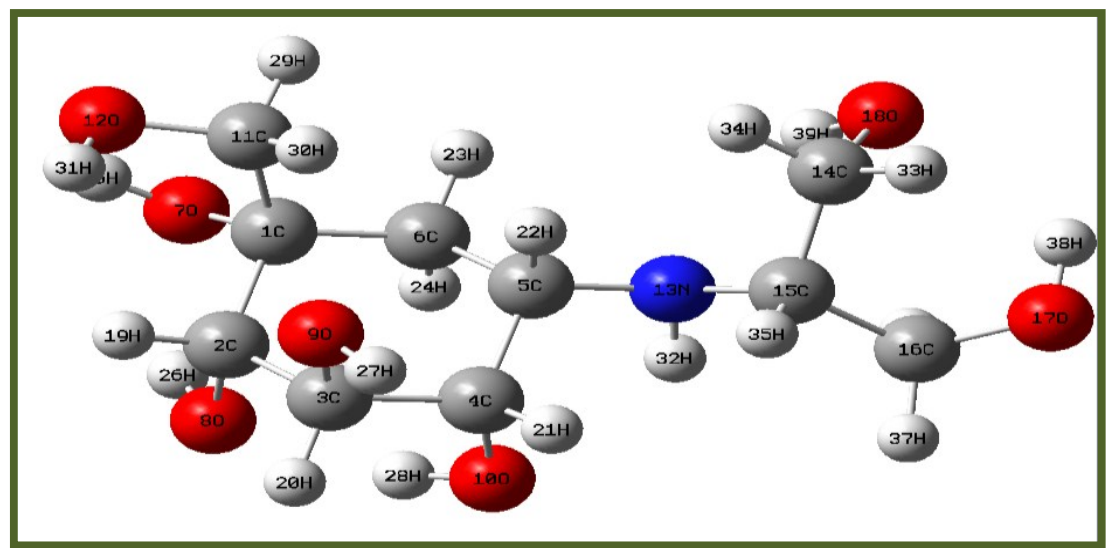

Fig.2. Optimized Molecular structure and atomic numbering of Voglibose

Table 1. Comparison of experimental and theoretical optimized parameter values of the Voglibose [bond length in $\left(\mathrm{A}^{\circ}\right)$, angles in $\left({ }^{\circ}\right)$ ]

\begin{tabular}{|c|c|c|c|c|c|c|c|c|}
\hline Bond length & B3LYP & $\operatorname{Exp}^{a}$ & Bond angle & B3LYP & $\operatorname{Exp}^{a}$ & Dihedral angle & B3LYP & $\operatorname{Exp}^{a}$ \\
\hline $\mathrm{C} 1-\mathrm{C} 2$ & 1.565 & & C2-C1-C6 & 110.9 & 109.0 & C6-C1-C2-C3 & 49.45 & \\
\hline C1-C6 & 1.536 & & $\mathrm{C} 2-\mathrm{C} 1-\mathrm{O} 7$ & 110.4 & 109.1 & $\mathrm{C} 6-\mathrm{C} 1-\mathrm{C} 2-\mathrm{O} 8$ & -74.16 & \\
\hline $\mathrm{C} 1-\mathrm{O} 7$ & 1.421 & 1.436 & C2-C1-C11 & 111.1 & 106.2 & C6-C1-C2-H19 & 168.77 & \\
\hline $\mathrm{C} 1-\mathrm{C} 11$ & 1.539 & & $\mathrm{C} 6-\mathrm{C} 1-\mathrm{O} 7$ & 104.7 & 110.9 & $\mathrm{O} 7-\mathrm{C} 1-\mathrm{C} 2-\mathrm{C} 3$ & 165.13 & \\
\hline $\mathrm{C} 2-\mathrm{C} 3$ & 1.544 & & C6-C1-C11 & 112.0 & 112.1 & $\mathrm{O} 7-\mathrm{C} 1-\mathrm{C} 2-\mathrm{O} 8$ & 41.51 & \\
\hline $\mathrm{C} 2-\mathrm{O} 8$ & 1.416 & 1.431 & O7-C1-C11 & 107.3 & 108.8 & O7-C1-C2-H19 & -75.54 & \\
\hline C2-H19 & 1.094 & & $\mathrm{C} 1-\mathrm{C} 2-\mathrm{C} 3$ & 113.1 & & $\mathrm{C} 11-\mathrm{C} 1-\mathrm{C} 2-\mathrm{C} 3$ & -75.82 & \\
\hline $\mathrm{C} 3-\mathrm{C} 4$ & 1.538 & & $\mathrm{C} 1-\mathrm{C} 2-\mathrm{O} 8$ & 112.0 & & $\mathrm{C} 11-\mathrm{C} 1-\mathrm{C} 2-\mathrm{O} 8$ & 160.55 & \\
\hline C3-O9 & 1.429 & 1.430 & C1-C2-H19 & 107.8 & & C11-C1-C2-H19 & 43.48 & \\
\hline C3-H20 & 1.098 & & $\mathrm{C} 3-\mathrm{C} 2-\mathrm{O} 8$ & 108.8 & & C2-C1-C6-C5 & -51.99 & \\
\hline $\mathrm{C} 4-\mathrm{C} 5$ & 1.540 & & C3-C2-H19 & 107.9 & & C2-C1-C6-H23 & -176.27 & \\
\hline C4-O10 & 1.428 & 1.429 & O8-C2-H19 & 106.6 & & C2-C1-C6-H24 & 69.08 & \\
\hline C4-H21 & 1.106 & & $\mathrm{C} 2-\mathrm{C} 3-\mathrm{C} 4$ & 111.9 & & $\mathrm{O} 7-\mathrm{C} 1-\mathrm{C} 6-\mathrm{C} 5$ & -171.12 & \\
\hline C5-C6 & 1.534 & & C2-C3-O9 & 109.7 & & $\mathrm{O} 7-\mathrm{C} 1-\mathrm{C} 6-\mathrm{H} 23$ & 64.60 & \\
\hline C5-N13 & 1.481 & 1.480 & $\mathrm{C} 2-\mathrm{C} 3-\mathrm{H} 20$ & 106.3 & & O7-C1-C6-H24 & -50.04 & \\
\hline $\mathrm{C} 5-\mathrm{H} 22$ & 1.101 & & C4-C3-O9 & 109.8 & & C11-C1-C6-C5 & 72.77 & \\
\hline $\mathrm{C} 6-\mathrm{H} 23$ & 1.094 & & $\mathrm{C} 4-\mathrm{C} 3-\mathrm{H} 20$ & 108.1 & & C11-C1-C6-H23 & -51.49 & \\
\hline C6-H24 & 1.094 & & O9-C3-H20 & 110.7 & & C11-C1-C6-H24 & -166.14 & \\
\hline $\mathrm{O} 7-\mathrm{H} 25$ & 0.969 & & $\mathrm{C} 3-\mathrm{C} 4-\mathrm{C} 5$ & 112.4 & & $\mathrm{C} 2-\mathrm{C} 1-\mathrm{O} 7-\mathrm{H} 25$ & 72.08 & \\
\hline $\mathrm{O} 8-\mathrm{H} 26$ & 0.971 & & C3-C4-O10 & 108.3 & & C6-C1-O7-H25 & -168.45 & \\
\hline O9-H27 & 0.965 & & $\mathrm{C} 3-\mathrm{C} 4-\mathrm{H} 21$ & 108.1 & & $\mathrm{C} 11-\mathrm{C} 1-\mathrm{O} 7-\mathrm{H} 25$ & -49.19 & \\
\hline $\mathrm{O} 10-\mathrm{H} 28$ & 0.973 & & C5-C4-O10 & 109.8 & & C2-C1-C11-O12 & -66.01 & \\
\hline $\mathrm{C} 11-\mathrm{O} 12$ & 1.431 & 1.417 & C5-C4-H21 & 108.5 & & C2-C1-C11-H29 & 175.37 & \\
\hline C11-H29 & 1.100 & & $\mathrm{O} 10-\mathrm{C} 4-\mathrm{H} 21$ & 109.4 & & C2-C1-C11-H30 & 54.96 & \\
\hline C11-H30 & 1.094 & & $\mathrm{C} 4-\mathrm{C} 5-\mathrm{C} 6$ & 110.4 & 110.2 & C6-C1-C11-O12 & 169.32 & \\
\hline O12-H31 & 0.964 & & C4-C5-N13 & 106.2 & 108.9 & C6-C1-C11-H29 & 50.71 & \\
\hline N13-C15 & 1.480 & 1.467 & C4-C5-H22 & 107.7 & & C6-C1-C11-H30 & -69.69 & \\
\hline N13-H32 & 1.019 & & C6-C5-N13 & 112.0 & 110.9 & $\mathrm{O} 7-\mathrm{C} 1-\mathrm{C} 11-\mathrm{O} 12$ & 54.81 & \\
\hline $\mathrm{C} 14-\mathrm{C} 15$ & 1.533 & & C6-C5-H22 & 109.3 & & $\mathrm{O} 7-\mathrm{C} 1-\mathrm{C} 11-\mathrm{H} 29$ & -63.79 & \\
\hline C14-O18 & 1.427 & & $\mathrm{~N} 13-\mathrm{C} 5-\mathrm{H} 22$ & 110.9 & & O7-C1-C11-H30 & 175.79 & \\
\hline C14-H33 & 1.092 & & C1-C6-C5 & 114.0 & & $\mathrm{C} 1-\mathrm{C} 2-\mathrm{C} 3-\mathrm{C} 4$ & -50.92 & \\
\hline C14-H34 & 1.096 & & C1-C6-H23 & 108.4 & & $\mathrm{C} 1-\mathrm{C} 2-\mathrm{C} 3-\mathrm{O} 9$ & 71.29 & \\
\hline $\mathrm{C} 15-\mathrm{C} 16$ & 1.548 & & $\mathrm{C} 1-\mathrm{C} 6-\mathrm{H} 24$ & 106.8 & & $\mathrm{C} 1-\mathrm{C} 2-\mathrm{C} 3-\mathrm{H} 20$ & -168.86 & \\
\hline C15-H35 & 1.100 & & C5-C6-H23 & 111.0 & & $\mathrm{O} 8-\mathrm{C} 2-\mathrm{C} 3-\mathrm{C} 4$ & 74.43 & \\
\hline C16-O17 & 1.411 & & C5-C6-H24 & 109.4 & & O8-C2-C3-O9 & -163.33 & \\
\hline C16-H36 & 1.101 & & H23-C6-H24 & 106.6 & & $\mathrm{O} 8-\mathrm{C} 2-\mathrm{C} 3-\mathrm{H} 20$ & -43.50 & \\
\hline C16-H37 & 1.095 & & $\mathrm{C} 1-\mathrm{O} 7-\mathrm{H} 25$ & 106.0 & & $\mathrm{H} 19-\mathrm{C} 2-\mathrm{C} 3-\mathrm{C} 4$ & -170.15 & \\
\hline O17-H38 & 0.969 & & $\mathrm{C} 2-\mathrm{O} 8-\mathrm{H} 26$ & 107.0 & & H19-C2-C3-O9 & -47.92 & \\
\hline
\end{tabular}




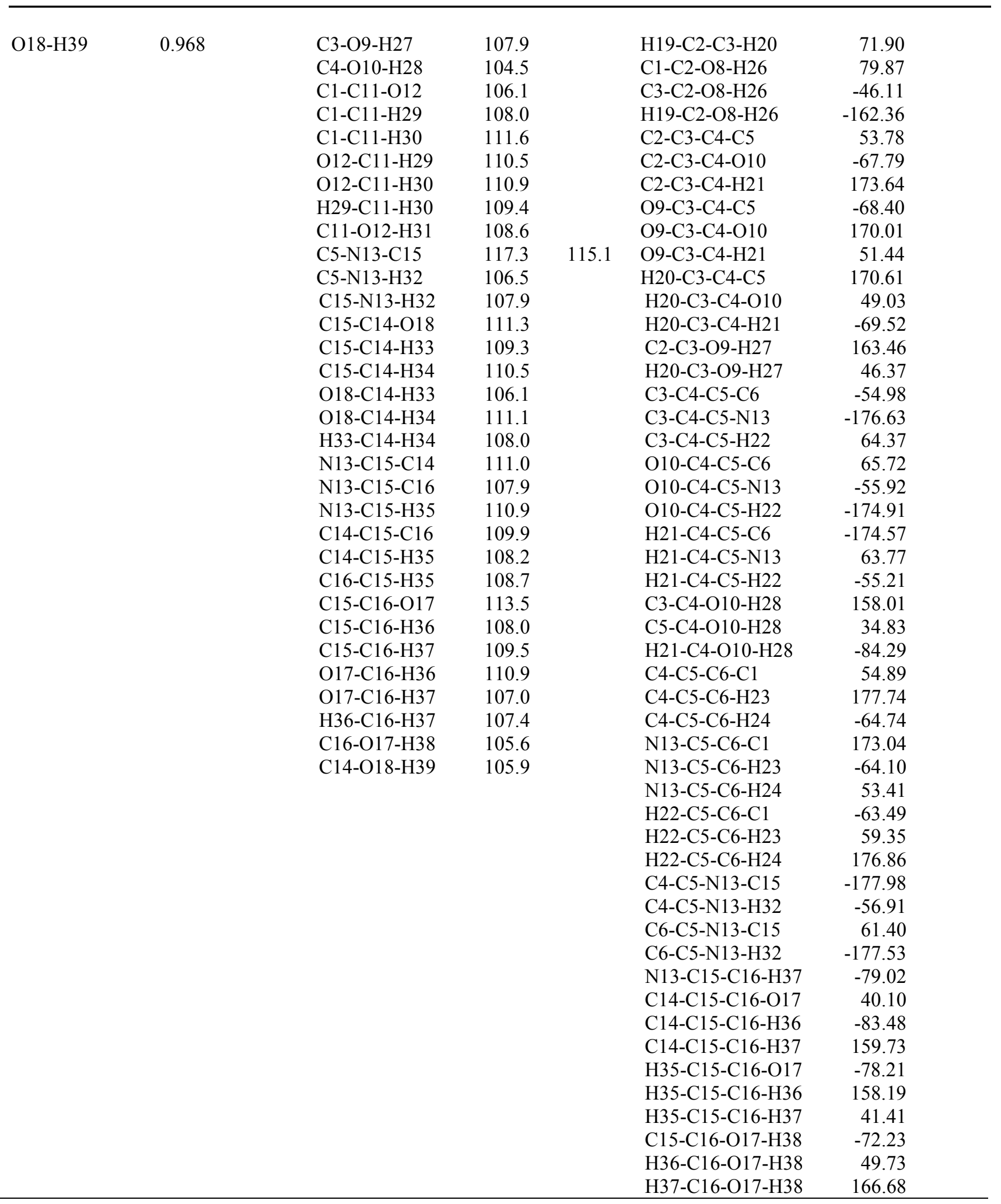

\subsection{Vibrational assignments}

The Voglibose molecule consists of 39 atoms, which undergoes 111 normal modes of vibrations. The molecule belongs to $C_{1}$ point group symmetry. On the assumption of $C_{1}$ group of symmetry, the 111 fundamental vibrations of the molecule can be distributed as 38 stretching, 75 in-plane bending and 26 out-of plane bending modes. The calculated wavenumbers, observed IR, Raman bands and assignments are given in Table 2 and their experimental and simulated spectra of IR and Raman are plotted in the Fig. 3 and Fig. 4, respectively. 


\subsubsection{Cyclohexane ring vibrations}

The C-C stretching vibration of the Cyclohexane ring observed the FTIR band at 1070,892 $\mathrm{cm}^{-1}$ and FT-Raman band at $698 \mathrm{~cm}^{-1}$ and the computed scaled wavenumbers at 1397, 1070, 895, $698 \mathrm{~cm}^{-1}$ by DFT method. These modes are good agreement with literature [18,19]. Guirgis et al.,2012 [20] assigned C-C-C in-plane bending vibration at $450,349,354 \mathrm{~cm}^{-1}$ by DFT method. In our present work C-C-C in-plane bending vibration observed at 937, 426, $421 \mathrm{~cm}^{-1}$ in FTIR spectrum and $440 \mathrm{~cm}^{-1}$ in FT-Raman spectrum and theoretically predicted wavenumbers at 939, 444 and $416 \mathrm{~cm}^{-1}$ by DFT method, which is good agreement with Cyclohexane derivatives $[18,19,20]$.

The heteroaromatic structure shows the presence of $\mathrm{C}-\mathrm{H}$ stretching vibration in the region $3100-3000 \mathrm{~cm}^{-1}$ which is the characteristics region for the ready identification of $\mathrm{C}-\mathrm{H}$ stretching vibration [21]. In our present work $\mathrm{C}-\mathrm{H}$ symmetric and anti symmetric stretching vibrations in ring $\mathrm{CH}_{2}$ identified at 2988 and $2976 \mathrm{~cm}^{-1}$ by DFT calculation. The ring $\mathrm{CH}_{2}$ anti symmetric stretching vibration observed at $2979 \mathrm{~cm}^{-1}$ in FT-Raman spectrum. The computed wavenumbers at 2970, 2948, 2917 and $2816 \mathrm{~cm}^{-1}$ by DFT method have been identified as C2-H19, C5-H22, C3-H20 and C4-H21 stretching vibrations respectively. The FTIR band at 1436 and $1233 \mathrm{~cm}^{-1}$ have been identified as scissoring and twisting type $\mathrm{CH}_{2}$ inplane bending vibration in ring respectively and computed wavenumbers at 1449 and $1216 \mathrm{~cm}^{-1}$ for this mode. The $\mathrm{C}-\mathrm{H}$ in-plane bending frequencies occur in the region $1300-1000 \mathrm{~cm}^{-1}$. The out-of-plane bending vibrations are strongly coupled vibration and occur in the region $1000-750 \mathrm{~cm}^{-1}[22]$. In our present work C-C-H in-plane bending vibrations observed at $1263 \mathrm{~cm}^{-1}$ in FT-Raman spectrum and the predicted wavenumbers at 1356, 1287, 1286 and $1260 \mathrm{~cm}^{-1}$ by DFT method. Mode.nos 78 and 93 has been identified as $\mathrm{CH}$ out-of plane bending vibration, which is good agreement with expected values [22].

\subsubsection{O-H vibrations}

Hydrogen bonding alerts the frequencies of the stretching and bending vibrations. The $\mathrm{O}-\mathrm{H}$ stretching bands move to lower frequencies usually with increase intensity and band broadening in the hydrogen bonded species. Hydrogen bonding present in five or six member ring system would reduce the $\mathrm{O}-\mathrm{H}$ stretching bands to 3550 to $3200 \mathrm{~cm}^{-1}$ region [23]. Our title molecule contains six $\mathrm{O}-\mathrm{H}$ groups, so we expect six O-H stretching vibrations. From the Table 2 which is evident that the mode no: 1-7 has been identified as $\mathrm{O}-\mathrm{H}$ stretching vibrations, these are pure modes and the PED exactly contributes to $100 \%$. The $\mathrm{O}-\mathrm{H}$ in-plane-bending vibration in phenol, in general, lies in the region 1250 to $1150 \mathrm{~cm}^{-1}$. In our present work, C-O-H in-plane bending vibrations observed at 1070 $\mathrm{cm}^{-1}$ in FT-IR spectrum and $1411,1377 \mathrm{~cm}^{-1}$ in FT-Raman spectrum. The calculated wavenumbers at $1415,1382,1374,1371,1360,1179,1168$ and $1156 \mathrm{~cm}^{-1}$ by DFT method has been identified as $\mathrm{C}-\mathrm{O}-\mathrm{H}$ in-plane bending vibrations. The $\mathrm{OH}$ out-of-plane deformation vibration for phenol lies in the 290 to $320 \mathrm{~cm}^{-1}$ region for free $\mathrm{OH}$ [21]. In our work $4 \mathrm{OH}$ groups directly attached to the Cyclohexane ring. The computed wavenumbers at 463, 438, 279 and $234 \mathrm{~cm}^{-1}$ by DFT method has been identified as the $\mathrm{O}-\mathrm{H}$ out-of plane bending vibrations. Mode no: 63, 66, 68, 70 and 73 has been identified as the $\mathrm{O}-\mathrm{H}$ out-of plane bending vibrations of the $\mathrm{CH}_{2} \mathrm{OH}$ group.

\subsubsection{Methylene group vibrations}

For the assignments of $\mathrm{CH}_{2}$ group frequencies, basically six fundamentals vibration can be associated to each $\mathrm{CH}_{2}$ group namely, $\mathrm{CH}_{2}$ symmetric stretch, antisymmetric stretch, scissoring and rocking modes, which belong to polarized in-plane vibrations . In addition to that, wagging and twisting mode of $\mathrm{CH}_{2}$ group would be expected to be depolarized for out-of-plane bending vibration. The asymmetric $\mathrm{CH}_{2}$ stretching vibration generally observed in the region 3000-2900 $\mathrm{cm}^{-1}$, while the $\mathrm{CH}_{2}$ symmetric stretch will appear between $2900 \mathrm{~cm}^{-1}$ and $2800 \mathrm{~cm}^{-1}$ [24]. For title molecule $\mathrm{CH}_{2}$ anti symmetric and symmetric stretching vibrations observed at $2979,2889 \mathrm{~cm}^{-1}$ and $2895 \mathrm{~cm}^{-1}$ in FT-Raman and FT-IR spectrum respectively. The computed wavenumbers at 3001 , 2976 and $2963 \mathrm{~cm}^{-1}$ and 2988, 2888, 2882 and $2876 \mathrm{~cm}^{-1}$ are assigned as $\mathrm{CH}_{2}$ anti symmetric and symmetric stretching vibrations. The $\mathrm{CH}_{2}$ scissoring vibrations appear normally in the region 1490 
$1435 \mathrm{~cm}^{-1}$ as medium intense bands [25]. In our present investigation FT-Raman band at $1460 \mathrm{~cm}^{-1}$ and computed wavenumbers at 1465,1464 and $1457 \mathrm{~cm}^{-1}$ have been identified as $\mathrm{CH}_{2}$ scissoring vibrations. Absorption of hydrocarbons due to $\mathrm{CH}_{2}$ twisting and wagging vibration is observed in the $1350-1150 \mathrm{~cm}^{-1}$ region [26]. For title molecule the FT-IR band at $1233 \mathrm{~cm}^{-1}$ and $1216 \mathrm{~cm}^{-1}$ by DFT calculation gives the $\mathrm{CH}_{2}$ twisting vibrations. Mode no: 53 have been identified as the $\mathrm{CH}_{2}$ Rocking mode.

\subsection{4. $\mathrm{N}-\mathrm{H}$ and $\mathrm{C}-\mathrm{N}$ vibrations}

The N-H stretching vibrations generally give rise to bands at $3500-3400 \mathrm{~cm}^{-1}$ [27]. For title molecule N-H stretching vibration observed at $3254 \mathrm{~cm}^{-1}$ in FT-Raman spectrum and computed at $3334 \mathrm{~cm}^{-1}$ by DFT method. The observed FT-Raman band at $3254 \mathrm{~cm}^{-1}$ and calculated scaled wavenumber at 3334 is cm $\mathrm{cm}^{-1}$ is red shifted by $146 \mathrm{~cm}^{-1}$ and $66 \mathrm{~cm}^{-1}$ respectively. The reason for this long deviation is due to presence of the $\mathrm{N} 13-\mathrm{H} 32 \ldots \mathrm{O} 10$ intra molecular interaction. This red shifting is got enhanced by the reduction in the N-H bond values occurring in the hydrogen bonding interactions. The $\mathrm{CNH}$ vibration where $\mathrm{N}$ and $\mathrm{H}$ atoms move in the same direction relative to the carbon atom gives rise to a weaker band [25] near $1250 \mathrm{~cm}^{-1}$. In our present study the theoretically predicted wave number at $1458 \mathrm{~cm}^{-1}$ gives the $\mathrm{CNH}$ in-plane bending vibration.

Silverstein et al., [26] assigned the C-N stretching absorption in the region 1382 to $1286 \mathrm{~cm}^{-}$ ${ }^{1}$ for aromatic amines. For title molecule C-N stretching vibration observed at $1134 \mathrm{~cm}^{-1}$ in FT-IR spectrum and 1136 and $1086 \mathrm{~cm}^{-1}$ in FT-Raman spectrum. The calculated wave numbers at 1135 and $1087 \mathrm{~cm}^{-1}$ has been identified as C-N stretching vibration, which is good agreement with experimental values. The calculated scaled wavenumber at $505 \mathrm{~cm}^{-1}$ by DFT method gives CNC inplane bending vibrations. The observed FT-Raman band at $377 \mathrm{~cm}^{-1}$ and computed wave number at $379 \mathrm{~cm}^{-1}$ by DFT method has been identified as CCNC out-of plane bending vibration.

\subsubsection{C-O vibrations}

The $\mathrm{C}-\mathrm{O}$ stretching vibration in phenol occurs as a strongest band in the region 1300 to $1200 \mathrm{~cm}^{-1}$ [28]. For title molecule C-O stretching vibration observed at $1026 \mathrm{~cm}^{-1}$ in FT-IR spectrum and $1047 \mathrm{~cm}^{-1}$ in FT-Raman spectrum. The calculated wavenumbers by DFT method at $1100,1063,1057,1049,1045,1032$ and $1008 \mathrm{~cm}^{-1}$ are assigned C-O stretching vibrations. The observed FT-Raman band at $630 \mathrm{~cm}^{-1}$ and theoretically predicted wavenumbers at $649,629,333$, 331,316 and $234 \mathrm{~cm}^{-1}$ are identified as C-C-O in-plane bending vibrations. The C-C-C-O out-of plane bending vibration observed at $397 \mathrm{~cm}^{-1}$ in FT-Raman band and calculated wavenumbers at 398, 339, and $251 \mathrm{~cm}^{-1}$ by DFT calculation. Mode nos: $105-109$ has been identified as C-C-C-O torsional modes. 

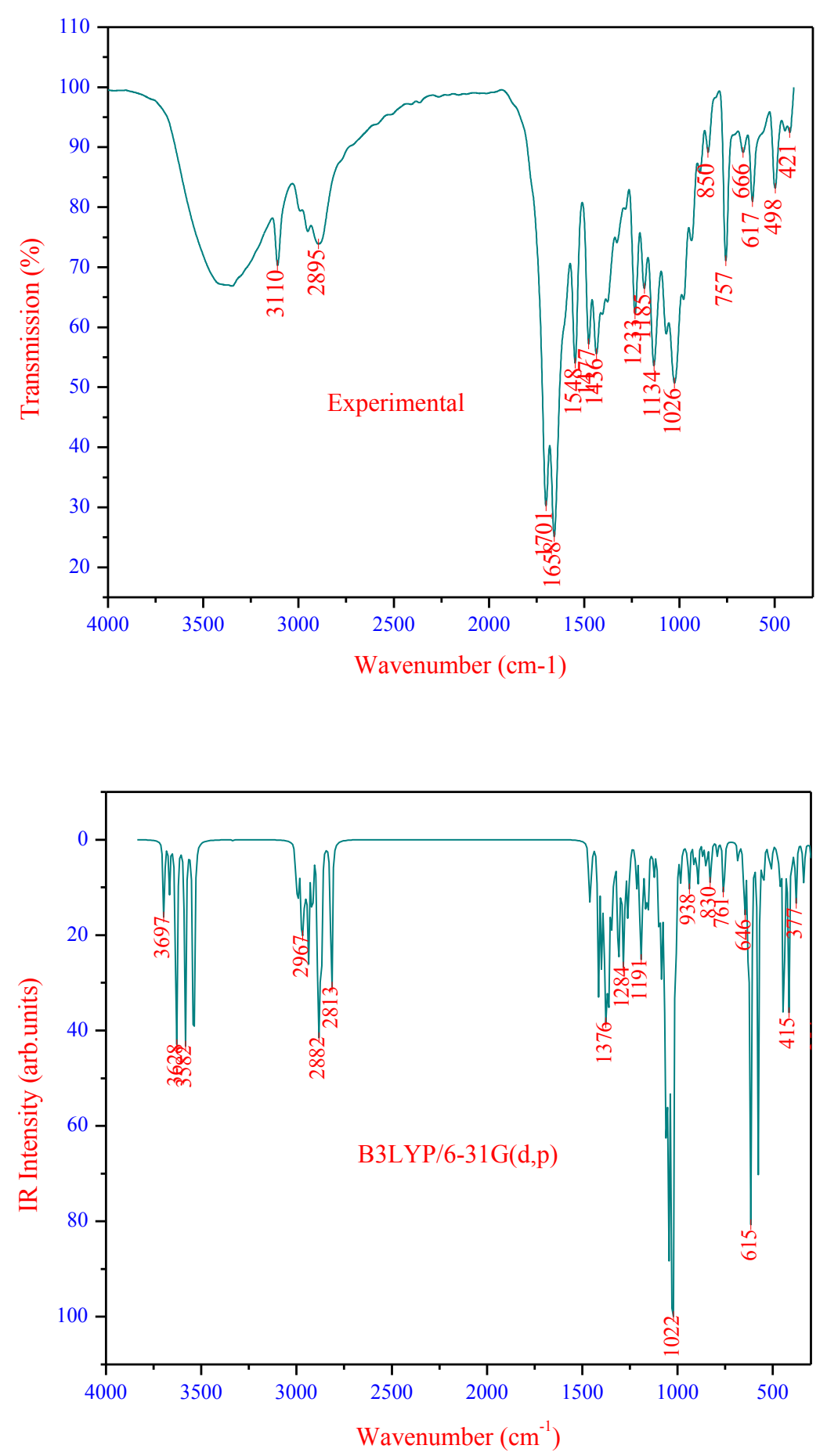

Fig. 3. Comparison of experimental and theoretical B3LYP/6-31G(d,p) FT-IR spectrum for Voglibose 

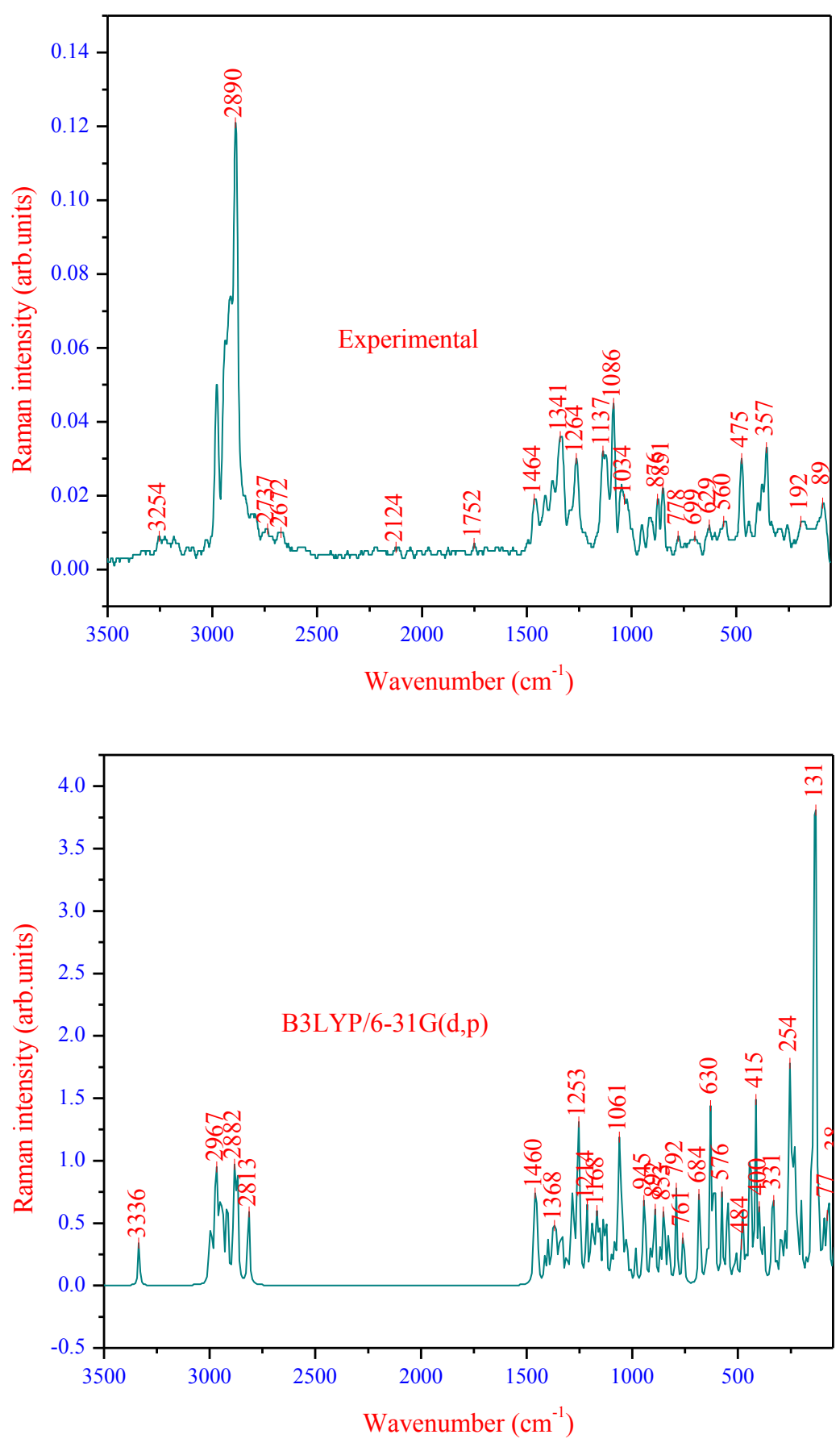

Fig.4. Comparison of experimental and theoretical B3LYP/6-31G(d,p) FT-Raman spectrum for Voglibose 
Table 2. Comparison of the experimental and calculated vibrational spectra and proposed assignments of Voglibose

\begin{tabular}{|c|c|c|c|c|c|c|c|}
\hline \multirow{3}{*}{$\begin{array}{l}\text { Mode } \\
\text { No }\end{array}$} & \multicolumn{2}{|c|}{$\begin{array}{c}\text { Experimental wave } \\
\text { numbers } / \mathrm{cm}^{-1}\end{array}$} & \multicolumn{4}{|c|}{ Theoretical wave numbers $/ \mathrm{cm}^{-1}$} & \multirow{3}{*}{$\begin{array}{l}\text { Vibrational assignments with PED } \\
\qquad(\geq \mathbf{1 0} \%)\end{array}$} \\
\hline & \multirow{2}{*}{ FT-IR } & \multirow{2}{*}{$\begin{array}{c}\text { FT- } \\
\text { Raman }\end{array}$} & \multicolumn{4}{|c|}{ B3LYP/6-31G(d,p) } & \\
\hline & & & Unscaled & scaled & $\mathbf{I}_{\mathrm{IR}}^{\mathrm{a}}$ & $\mathbf{I}_{\mathbf{R a}}^{\mathbf{b}}$ & \\
\hline 1 & & & 3846 & 3695 & 44.46 & 3.09 & $v_{\mathrm{O} 12 \mathrm{H} 31(100)}$ \\
\hline 2 & & & 3816 & 3666 & 33.39 & 2.82 & $v_{\mathrm{O} 9 \mathrm{H} 27(100)}$ \\
\hline 3 & & & 3784 & 3636 & 31.97 & 1.67 & $v_{\mathrm{O} 18 \mathrm{H} 39(100)}$ \\
\hline 4 & & & 3779 & 3631 & 51.69 & 2.45 & $v_{\mathrm{O} 7 \mathrm{H} 25(100)}$ \\
\hline 5 & & & 3775 & 3627 & 49.99 & 1.87 & $v_{\mathrm{O} 17 \mathrm{H} 38(100)}$ \\
\hline 6 & & & 3730 & 3584 & 72.26 & 1.33 & $v_{\mathrm{O} 18 \mathrm{H} 39(100)}$ \\
\hline 7 & & & 3684 & 3540 & 90.59 & 2.65 & $v_{\mathrm{O} 8 \mathrm{H} 26(100)}$ \\
\hline 8 & & 3254 & 3470 & 3334 & 4.93 & 2.95 & $v_{\mathrm{N} 13 \mathrm{H} 32(98)}$ \\
\hline 9 & & & 3123 & 3001 & 37.79 & 3.89 & $v_{\mathrm{C} 14 \mathrm{H} 33(96) \text { anti.sym } \mathrm{CH} 2}$ \\
\hline 10 & & & 3110 & 2988 & 32.98 & 2.82 & $v_{\mathrm{C} 6 \mathrm{H} 23(64) \text { sym in ring } \mathrm{CH} 2}$ \\
\hline 11 & & 2979 & 3097 & 2976 & 33.48 & 3.00 & $v_{\mathrm{C} 6 \mathrm{H} 24(32) \text { ant.sym in ring } \mathrm{CH} 2}$ \\
\hline 12 & & & 3091 & 2970 & 34.62 & 4.93 & $v_{\mathrm{C} 2 \mathrm{H} 19(93)}$ \\
\hline 13 & & & 3084 & 2963 & 45.7 & 4.22 & $v_{\mathrm{C} 11 \mathrm{H} 29(68) \text { ant.sym in } \mathrm{CH} 2}$ \\
\hline 14 & 2951 & & 3068 & 2948 & 40.31 & 5.38 & $v_{\mathrm{C} 5 \mathrm{H} 22(47) \text { in ring }}$ \\
\hline 15 & & & 3055 & 2935 & 49.46 & 3.39 & $v_{\mathrm{C} 5 \mathrm{H} 22(46) \text { in ring }}$ \\
\hline 16 & & 2912 & 3036 & 2917 & 48.4 & 5.54 & $v_{\mathrm{C} 3 \mathrm{H} 20(73) \text { in ring }}$ \\
\hline 17 & 2895 & 2889 & 3006 & 2888 & 49.19 & 2.89 & $v_{\mathrm{C} 16 \mathrm{H} 36(91) \text { sym in } \mathrm{CH} 2}$ \\
\hline 18 & & & 3000 & 2882 & 54.89 & 4.62 & $v_{\mathrm{C} 11 \mathrm{H} 9(95) \mathrm{sym} \text { in } \mathrm{CH} 2}$ \\
\hline 19 & & & 2993 & 2876 & 44.4 & 3.63 & $v_{\mathrm{C} 14 \mathrm{H} 34(91) \text { sym in } \mathrm{CH} 2}$ \\
\hline 20 & & & 2985 & 2868 & 47.69 & 4.85 & $v_{\mathrm{C} 15 \mathrm{H} 35(93)}$ \\
\hline 21 & & & 2931 & 2816 & 71.28 & 5.33 & $v_{\mathrm{C} 4 \mathrm{H} 21(93) \text { in ring }}$ \\
\hline 22 & & & 1525 & 1465 & 18.85 & 4.93 & $\delta_{\mathrm{sciH} 36 \mathrm{C} 16 \mathrm{H} 37(56)}$ \\
\hline 23 & & & 1524 & 1464 & 22.43 & 5.48 & $\delta_{\mathrm{sciH} 33 \mathrm{C} 14 \mathrm{H} 34(56)}$ \\
\hline 24 & & & 1518 & 1458 & 29.11 & 3.61 & $\delta_{\mathrm{H} 32 \mathrm{~N} 13 \mathrm{C} 15(63)}$ \\
\hline 25 & & 1460 & 1516 & 1457 & 20.99 & 7.64 & $\delta_{\mathrm{sciH} 36 \mathrm{C} 16 \mathrm{H} 37(56)}$ \\
\hline 26 & 1436 & & 1508 & 1449 & 17.22 & 5.98 & $\delta_{\text {sciH23C6H24(84) in Ring }+} \gamma_{\mathrm{C} 11 \mathrm{C} 1 \mathrm{O} 12 \mathrm{H} 30(42)}$ \\
\hline 27 & & 1411 & 1473 & 1415 & 58.17 & 4.35 & $\delta_{\mathrm{H} 28 \mathrm{O} 10 \mathrm{C} 4(55)+} \gamma_{\mathrm{C} 4 \mathrm{C} 5 \mathrm{O} 10 \mathrm{H} 21(28)}$ \\
\hline 28 & & & 1458 & 1401 & 21.16 & 4.65 & $\delta_{\mathrm{H} 26 \mathrm{O} 8 \mathrm{C} 2(20)+} \gamma_{\mathrm{C} 3 \mathrm{C} 4 \mathrm{O} 9 \mathrm{H} 20(10)}$ \\
\hline 29 & & & 1454 & 1397 & 52.62 & 4.47 & $v_{\mathrm{C} 2 \mathrm{C} 3(11) \text { in ring }+} \delta_{\mathrm{H} 27 \mathrm{O} 9 \mathrm{C} 3(14)}$ \\
\hline 30 & & & 1438 & 1382 & 46.56 & 3.83 & $\delta_{\mathrm{H} 25 \mathrm{O} 7 \mathrm{C} 1(21)+} \gamma_{\mathrm{C} 14 \mathrm{H} 33 \mathrm{C} 15 \mathrm{H} 34(20)}$ \\
\hline 31 & & 1377 & 1430 & 1374 & 43.12 & 2.51 & $\begin{array}{l}\delta_{\mathrm{H} 38 \mathrm{O} 17 \mathrm{C} 16(32)+} \gamma_{\mathrm{C} 16 \mathrm{C} 15 \mathrm{O} 17 \mathrm{H} 36(11)+} \\
\tau_{\mathrm{H} 37 \mathrm{C} 16 \mathrm{C} 15 \mathrm{C} 14(14)}\end{array}$ \\
\hline 32 & & & 1428 & 1372 & 52.23 & 7.79 & $\delta_{\mathrm{H} 36 \mathrm{C} 16 \mathrm{O} 17(41)}$ \\
\hline 33 & & & 1419 & 1363 & 45.79 & 4.09 & $\delta_{\mathrm{H} 38017 \mathrm{C} 16(20)}$ \\
\hline 34 & & & 1416 & 1360 & 35.84 & 4.04 & $\delta_{\mathrm{H} 27 \mathrm{C} 3 \mathrm{O} 9(45)}$ \\
\hline 35 & & & 1411 & 1356 & 33.92 & 4.11 & $\delta_{\mathrm{H} 22 \mathrm{C} 5 \mathrm{C} 6(24)}$ \\
\hline 36 & & & 1399 & 1344 & 39.13 & 4.85 & $\delta_{\mathrm{H} 29 \mathrm{C} 11 \mathrm{O} 12(35)}$ \\
\hline 37 & 1329 & 1334 & 1388 & 1334 & 27.87 & 7.85 & $\delta_{\mathrm{H} 20 \mathrm{C} 3 \mathrm{O} 9(37)+} \gamma_{\mathrm{C} 15 \mathrm{C} 16 \mathrm{~N} 13 \mathrm{H} 35(30)}$ \\
\hline 38 & & & 1368 & 1314 & 40.48 & 3.71 & $\delta_{\mathrm{H} 25 \mathrm{O} 7 \mathrm{C} 1(29)+} \gamma_{\mathrm{C} 5 \mathrm{C} 6 \mathrm{~N} 13 \mathrm{H} 22(36)}$ \\
\hline 39 & & & 1358 & 1305 & 51.23 & 3.73 & $\delta_{\mathrm{H} 25 \mathrm{O} 7 \mathrm{C} 1(29)+} \gamma_{\mathrm{C} 5 \mathrm{C} 6 \mathrm{~N} 13 \mathrm{H} 22(36)}$ \\
\hline 40 & & & 1339 & 1287 & 29.93 & 7.98 & $\delta_{\mathrm{H} 21 \mathrm{C} 4 \mathrm{C} 5(37)}$ \\
\hline 41 & & & 1338 & 1286 & 48.2 & 6.00 & $\delta_{\mathrm{H} 22 \mathrm{C} 5 \mathrm{C} 6(11)+} \gamma_{\mathrm{C} 5 \mathrm{C} 6 \mathrm{~N} 13 \mathrm{H} 22(10)+} \tau_{\mathrm{H} 24 \mathrm{C} 6 \mathrm{C} 5 \mathrm{C} 4(13)}$ \\
\hline 42 & & & 1326 & 1274 & 35.09 & 6.99 & $\tau_{\mathrm{C} 2 \mathrm{H} 19 \mathrm{O} 8 \mathrm{H} 26(40)}$ \\
\hline 43 & & 1263 & 1311 & 1260 & 37.6 & 6.66 & $\delta_{\mathrm{H} 22 \mathrm{C} 5 \mathrm{C} 6(13)}$ \\
\hline 44 & & & 1307 & 1256 & 17.37 & 9.09 & $\delta_{\mathrm{H} 29 \mathrm{C} 11 \mathrm{H} 30(43)}$ \\
\hline 45 & & & 1301 & 1250 & 20.21 & 11.09 & $\gamma_{\mathrm{C} 4 \mathrm{C} 5 \mathrm{O} 10 \mathrm{H} 21(14)}$ \\
\hline 46 & 1233 & & 1266 & 1216 & 32.67 & 9.10 & $\delta_{\mathrm{twist} H 29 \mathrm{C} 11 \mathrm{H} 30(33)+} \delta_{\mathrm{twistH} 23 \mathrm{C} 6 \mathrm{H} 24(43) \text { in ring }}$ \\
\hline 47 & & & 1244 & 1195 & 51.12 & 5.88 & $\delta_{\mathrm{H} 19 \mathrm{C} 2 \mathrm{C} 3(20)+} \gamma_{\mathrm{C} 4 \mathrm{C} 5 \mathrm{O} 10 \mathrm{H} 21(11)}$ \\
\hline 48 & 1185 & & 1236 & 1188 & 47.36 & 7.95 & $\delta_{\mathrm{H} 23 \mathrm{C} 6 \mathrm{Cl}(15)}+\gamma_{\mathrm{C} 3 \mathrm{C} 4 \mathrm{O} 9 \mathrm{H} 20(16)}$ \\
\hline 49 & & & 1227 & 1179 & 15.77 & 4.51 & $\delta_{\mathrm{H} 39 \mathrm{O} 18 \mathrm{C} 14(15)}$ \\
\hline 50 & & & 1216 & 1168 & 33.03 & 7.59 & $\delta_{\mathrm{H} 33 \mathrm{C} 14 \mathrm{O} 18(39)}$ \\
\hline 51 & & & 1203 & 1156 & 48.55 & 8.98 & $\delta_{\mathrm{H} 31 \mathrm{C} 11 \mathrm{O} 12(59)}$ \\
\hline 52 & 1134 & 1136 & 1181 & 1135 & 10.62 & 9.19 & $v_{\mathrm{N} 13 \mathrm{C} 5(11)}$ \\
\hline 53 & & & 1169 & 1123 & 25.65 & 7.53 & $\delta_{\text {rockH29C11H30(59) }}$ \\
\hline 54 & & & 1145 & 1100 & 37.97 & 4.75 & $v_{\mathrm{O} 10 \mathrm{C} 4(11)}$ \\
\hline
\end{tabular}




\begin{tabular}{|c|c|c|c|c|c|c|c|}
\hline 55 & & 1087 & 1131 & 1087 & 59.4 & 6.92 & $v_{\mathrm{N} 13 \mathrm{C} 5(23)}$ \\
\hline 56 & 1070 & & 1114 & 1070 & 42.99 & 7.10 & $v_{\mathrm{C} 2 \mathrm{C} 3(16)+} \delta_{\mathrm{H} 31 \mathrm{O} 12 \mathrm{C} 11(11)}$ \\
\hline 57 & & & 1106 & 1063 & 69.69 & 11.34 & $v_{\mathrm{O} 17 \mathrm{C} 16(61)}$ \\
\hline 58 & & & 1100 & 1057 & 56.01 & 10.12 & $v_{\mathrm{O} 7 \mathrm{Cl}(14)}$ \\
\hline 59 & & & 1092 & 1049 & 61.85 & 6.56 & $v_{\mathrm{O} 12 \mathrm{C} 11(13)}$ \\
\hline 60 & & 1047 & 1088 & 1045 & 75.34 & 4.86 & $v_{\mathrm{O} 9 \mathrm{C} 3(46)}$ \\
\hline 61 & & & 1075 & 1033 & 23.11 & 5.88 & $v_{\mathrm{O} 8 \mathrm{C} 2(30)}$ \\
\hline 62 & 1026 & & 1074 & 1032 & 100 & 4.33 & $v_{\mathrm{O} 8 \mathrm{C} 2(21)}$ \\
\hline 63 & & & 1063 & 1021 & 97.92 & 5.42 & $v_{\mathrm{O} 18 \mathrm{C} 14(16)+} \gamma_{\mathrm{C} 14 \mathrm{C} 15 \mathrm{O} 18 \mathrm{H} 33}$ \\
\hline 64 & & & 1049 & 1008 & 39.34 & 3.56 & $v_{\mathrm{O} 12 \mathrm{C} 11(16)}$ \\
\hline 65 & 978 & & 1024 & 984 & 26.31 & 6.52 & $v_{\mathrm{O} 10 \mathrm{C} 4(21)}$ \\
\hline 66 & & 950 & 986 & 947 & 19.54 & 10.86 & $\gamma_{\mathrm{C} 16 \mathrm{C} 15 \mathrm{O} 17 \mathrm{H} 36(28)}$ \\
\hline 67 & 937 & & 977 & 939 & 31.25 & 7.71 & $\delta_{\mathrm{C} 2 \mathrm{C} 3 \mathrm{C} 4(11)}$ \\
\hline 68 & & 914 & 949 & 912 & 25 & 7.79 & $v_{\mathrm{N} 13 \mathrm{C} 15(10)+} \delta_{\mathrm{C} 2 \mathrm{C} 3 \mathrm{C} 4(20)+} \gamma_{\mathrm{C} 14 \mathrm{C} 15 \mathrm{O} 18 \mathrm{H} 33(27)}$ \\
\hline 69 & 892 & & 931 & 895 & 37.29 & 12.21 & $v_{\mathrm{C} 4 \mathrm{C} 5(12)}$ \\
\hline 70 & & 874 & 902 & 867 & 17.85 & 7.14 & $v_{\mathrm{O} 7 \mathrm{C} 1(30)+} \gamma_{\mathrm{C} 11 \mathrm{C} 1 \mathrm{O} 12 \mathrm{H} 30(16)}$ \\
\hline 71 & 850 & 850 & 885 & 850 & 29.51 & 13.00 & $v_{\mathrm{C} 14 \mathrm{C} 15(10)+} \gamma_{\mathrm{N} 13 \mathrm{C} 5 \mathrm{C} 15 \mathrm{H} 32(10)}$ \\
\hline 72 & & & 861 & 827 & 37.33 & 10.10 & $\gamma_{\mathrm{N} 13 \mathrm{C} 5 \mathrm{C} 15 \mathrm{H} 32(30)}+v_{\mathrm{C} 14 \mathrm{C} 15(40)}$ \\
\hline 73 & & 776 & 823 & 791 & 18.39 & 12.63 & $v_{\mathrm{C} 14 \mathrm{C} 15(38)+} \gamma_{\mathrm{N} 13 \mathrm{C} 5 \mathrm{C} 15 \mathrm{H} 32(39)+} \gamma_{\mathrm{C} 16 \mathrm{C} 15 \mathrm{O} 17 \mathrm{H} 36(10)}$ \\
\hline 74 & 757 & & 789 & 758 & 44.32 & 11.32 & $v_{\mathrm{C} 1 \mathrm{C} 11(22)}$ \\
\hline 75 & & 698 & 710 & 682 & 22.84 & 15.04 & $v_{\mathrm{C} 4 \mathrm{C} 5(20)}$ \\
\hline 76 & & & 675 & 649 & 46.35 & 8.51 & $\delta_{\mathrm{C} 1 \mathrm{C} 11 \mathrm{O} 12(21)}$ \\
\hline 77 & & 630 & 655 & 629 & 46.57 & 20.00 & $\delta_{\mathrm{C} 1 \mathrm{C} 11 \mathrm{O} 12(31)}$ \\
\hline 78 & 617 & & 641 & 616 & 94.83 & 10.36 & $\gamma_{\mathrm{H} 23 \mathrm{C} 6 \mathrm{C} 5 \mathrm{C} 4(12)}$ \\
\hline 79 & & & 634 & 609 & 33.63 & 14.57 & $\tau_{\mathrm{H} 28 \mathrm{O} 10 \mathrm{C} 4 \mathrm{C} 3(51)}$ \\
\hline 81 & & 553 & 571 & 549 & 35.45 & 18.29 & $\tau_{\mathrm{H} 39 \mathrm{O} 18 \mathrm{C} 14 \mathrm{C} 15(21)}$ \\
\hline 82 & & & 539 & 518 & 23.93 & 7.77 & $\delta_{\mathrm{C} 16 \mathrm{C} 15 \mathrm{~N} 13(31)}$ \\
\hline 83 & & & 526 & 505 & 24.88 & 9.01 & $\delta_{\mathrm{C} 5 \mathrm{~N} 13 \mathrm{C} 15(10)+} \tau_{\mathrm{H} 39 \mathrm{O} 18 \mathrm{C} 14 \mathrm{C} 15(11)}$ \\
\hline 84 & 480 & 475 & 499 & 479 & 13.98 & 16.75 & $\gamma_{\mathrm{C} 11 \mathrm{C} 2 \mathrm{C} 6 \mathrm{C} 1(11)}$ \\
\hline 85 & & & 482 & 463 & 31.8 & 8.22 & $\gamma_{\mathrm{H} 28 \mathrm{O} 10 \mathrm{C} 4 \mathrm{C} 5(11)}$ \\
\hline 86 & 446 & 440 & 462 & 444 & 65.76 & 20.07 & $\delta_{\mathrm{C} 2 \mathrm{C} 1 \mathrm{C} 6(11)}$ \\
\hline 87 & & & 456 & 438 & 34.99 & 14.46 & $\gamma_{\mathrm{H} 25 \mathrm{O} 7 \mathrm{C} 1 \mathrm{C} 6(11)}$ \\
\hline 88 & 421 & & 433 & 416 & 62.42 & 24.67 & $\delta_{\mathrm{C} 3 \mathrm{C} 4 \mathrm{C} 5(13)}$ \\
\hline 89 & & 397 & 414 & 398 & 20.04 & 16.66 & $\gamma_{\mathrm{C} 1 \mathrm{C} 6 \mathrm{C} 11 \mathrm{O} 7(21)}$ \\
\hline 90 & & 377 & 394 & 379 & 40.8 & 15.22 & $\delta_{\mathrm{C} 14 \mathrm{C} 15 \mathrm{~N} 13(19)+} \gamma_{\mathrm{C} 16 \mathrm{C} 14 \mathrm{~N} 13 \mathrm{C} 15(16)}$ \\
\hline 91 & & & 353 & 339 & 30.23 & 15.53 & $\delta_{\mathrm{C} 1 \mathrm{C} 2 \mathrm{O} 8(31)+} \tau_{\mathrm{H} 31 \mathrm{O} 12 \mathrm{C} 11 \mathrm{C} 1(73)+} \gamma_{\mathrm{C} 1 \mathrm{C} 6 \mathrm{C} 11 \mathrm{O} 7(11)}$ \\
\hline 92 & & & 345 & 331 & 15.18 & 18.14 & $\delta_{\mathrm{C} 6 \mathrm{C} 1 \mathrm{O} 7(19)}$ \\
\hline 93 & & & 329 & 316 & 5 & 8.16 & $\delta_{\mathrm{C} 5 \mathrm{C} 4 \mathrm{O} 10(14)+} \gamma_{\mathrm{H} 23 \mathrm{C} 6 \mathrm{C} 5 \mathrm{C} 4(10)}$ \\
\hline 94 & & & 308 & 296 & 24.68 & 18.69 & $\delta_{\mathrm{C} 2 \mathrm{C} 3 \mathrm{O} 9(19)+} \gamma_{\mathrm{C} 11 \mathrm{C} 2 \mathrm{C} 6 \mathrm{C} 1(20)}$ \\
\hline 95 & & & 290 & 279 & 16.21 & 15.52 & $\gamma_{\mathrm{H} 27 \mathrm{O} 9 \mathrm{C} 3 \mathrm{C} 2(58)}$ \\
\hline 96 & & 257 & 271 & 260 & 15.2 & 20.30 & $\tau_{\mathrm{C} 15 \mathrm{C} 14 \mathrm{O} 18 \mathrm{H} 39(46)}$ \\
\hline 97 & & & 261 & 251 & 74.46 & 40.47 & $\gamma_{\mathrm{C} 4 \mathrm{C} 3 \mathrm{C} 5 \mathrm{O} 10(10)}$ \\
\hline 98 & & & 244 & 234 & 45.48 & 33.89 & $\delta_{\mathrm{C} 15 \mathrm{C} 14 \mathrm{O} 18(16)+}+\gamma_{\mathrm{H} 26 \mathrm{O} 8 \mathrm{C} 3 \mathrm{C} 2(48)}$ \\
\hline 99 & & & 235 & 226 & 11.65 & 15.78 & $\gamma_{\mathrm{C} 11 \mathrm{C} 2 \mathrm{C} 6 \mathrm{C} 1(17)}$ \\
\hline 100 & & & 227 & 218 & 20.99 & 16.53 & $\delta_{\mathrm{C} 6 \mathrm{C} 1 \mathrm{C} 11(28)}$ \\
\hline 101 & & & 208 & 200 & 18.72 & 22.95 & $\delta_{\mathrm{C} 2 \mathrm{C} 3 \mathrm{O} 9(13)+} \tau_{\mathrm{C} 3 \mathrm{C} 2 \mathrm{C} 1 \mathrm{C} 6(12)}$ \\
\hline 102 & & 178 & 182 & 175 & 12.38 & 11.85 & $\tau_{\mathrm{C} 1 \mathrm{C} 2 \mathrm{C} 3 \mathrm{O} 9(35)}$ \\
\hline 103 & & & 157 & 151 & 54.09 & 34.87 & $\tau_{\mathrm{O} 31 \mathrm{C} 1 \mathrm{C} 11 \mathrm{O} 12(55)}$ \\
\hline 104 & & & 140 & 135 & 64.73 & 100.00 & $\delta_{\mathrm{C} 5 \mathrm{~N} 13 \mathrm{C} 15(20)}$ \\
\hline 105 & & & 123 & 118 & 12.2 & 21.49 & $\tau_{\mathrm{C} 16 \mathrm{C} 15 \mathrm{C} 14 \mathrm{O} 18}$ \\
\hline 106 & & & 98 & 94 & 13.97 & 24.33 & $\tau_{\mathrm{C} 14 \mathrm{C} 15 \mathrm{C} 16 \mathrm{O} 38(45)}$ \\
\hline 107 & & & 95 & 91 & 15.09 & 17.58 & $\tau_{\mathrm{C} 14 \mathrm{C} 15 \mathrm{C} 18 \mathrm{O} 39(49)}$ \\
\hline 108 & & 86 & 83 & 80 & 3.16 & 21.65 & $\tau_{\mathrm{C} 14 \mathrm{C} 15 \mathrm{C} 16 \mathrm{O} 17(38)}$ \\
\hline 109 & & & 75 & 72 & 8.34 & 46.95 & $\tau_{\mathrm{C} 6 \mathrm{C} 1 \mathrm{C} 11 \mathrm{O} 12(55)}$ \\
\hline 110 & & & 42 & 40 & 14.13 & 46.18 & $\delta_{\mathrm{C} 5 \mathrm{~N} 13 \mathrm{C} 15(15)+} \tau_{\mathrm{C} 5 \mathrm{~N} 13 \mathrm{C} 15 \mathrm{C} 14(44)}$ \\
\hline 111 & & & 40 & 38 & 6.65 & 48.75 & $\tau_{\mathrm{C} 6 \mathrm{C} 5 \mathrm{~N} 13 \mathrm{C} 15(57)}$ \\
\hline
\end{tabular}

$\nu$-stretching; $\delta$-in-plane-bending; $\gamma$-out-of-plane bending; $\tau$-torsion; w-weak; s-strong; vs-very strong; vw-very weak; m-medium.

${ }^{\mathrm{a}} \mathrm{I}_{\mathrm{IR}}$-IR Intensity $\left(\mathrm{Kmmol}^{-1}\right)$;

${ }^{\mathrm{b}} \mathrm{I}_{\mathrm{Ra}}$-Raman intensity (Arb units) (intensity normalized to $100 \%$ ). 


\subsection{NBO analysis}

In the NBO analysis [29], all possible interactions between "filled" (donor) Lewis-type NBOs and "empty" (acceptor) non-Lewis NBOs were investigated. The energies of these interactions were calculated second-order perturbation theory. These interactions (or energetic stabilizations) are named as 'delocalization' corrections to the zeroth-order natural Lewis structure. For each donor NBO (i) and acceptor NBO (j); the stabilization energy E associated with $\mathrm{i} \rightarrow \mathrm{j}$ delocalization, is explicitly estimated by the following equation:

$$
E_{2}=\Delta E_{i j}=q_{i} \frac{F(i, j)^{2}}{\varepsilon_{j}-\varepsilon_{i}}
$$

where $\mathrm{q}_{\mathrm{i}}$ is the donor orbital occupancy, are $\varepsilon_{\mathrm{i}}$ and $\varepsilon_{\mathrm{j}}$ diagonal elements and $\mathrm{F}(\mathrm{i}, \mathrm{j})$ is the off diagonal NBO Fock matrix element.

The interactions $\sigma(\mathrm{C} 2-\mathrm{H} 19) \rightarrow \sigma^{*}(\mathrm{C} 1-\mathrm{C} 6)$ and $\sigma^{*}(\mathrm{C} 3-\mathrm{C} 4)$ having the stabilization energy is $3.08,3.27 \mathrm{KJ} \mathrm{mol}^{-1}$ and $\sigma(\mathrm{C} 3-\mathrm{H} 20) \rightarrow \sigma^{*}(\mathrm{C} 1-\mathrm{C} 2)$ having the stabilization energy is $3.24 \mathrm{KJ} \mathrm{mol}^{-1}$ are responsible for conjugation of respective $\sigma$-bonds in Cyclohexane ring (Table 3). The intramolecular interaction is formed by the orbital overlap between $\mathrm{LP}(1) \mathrm{N} 13 \rightarrow \pi^{*}(\mathrm{O} 10-\mathrm{H} 28)$ bond orbital, which results intramolecular charge transfer causing stabilization energy $4.86 \mathrm{KJ} \mathrm{mol}^{-1}$ of the system. The energy contribution of $\mathrm{LP}(2) \mathrm{O} 17 \rightarrow \pi^{*}(\mathrm{C} 15-\mathrm{C} 16), \mathrm{LP}(2) \mathrm{O} 18 \rightarrow \pi^{*}(\mathrm{C} 15-\mathrm{H} 35)$, $\mathrm{LP}(2) \mathrm{O} 10 \rightarrow \pi^{*}(\mathrm{C} 4-\mathrm{H} 21)$ are $9.07,6.38,7.65 \mathrm{KJ} \mathrm{mol}^{-1}$, respectively, and hence there is a possibility for delocalization of lone pair (LP) of electrons between $\mathrm{O} 17$ and C15-C16 and O10 and C4-H21.

Table 3. Second order Perturbation theory analysis of Fock Matrix in NBO basis forVoglibose.

\begin{tabular}{|c|c|c|c|c|c|c|}
\hline Donor (i) & $E_{D}(i)(e)$ & Acceptor(j) & $E_{D}(j)(e)$ & $\begin{array}{c}\mathrm{E}^{(2) \mathrm{a}} \mathrm{KJ} \\
\mathrm{mol}^{-1}\end{array}$ & $\begin{array}{c}\mathrm{E}(\mathrm{j})-\mathrm{E}(\mathrm{i})^{\mathrm{b}} \\
\text { a.u }\end{array}$ & $\begin{array}{c}\mathrm{F}(\mathrm{i}, \mathrm{j})^{\mathrm{c}} \\
\text { a.u }\end{array}$ \\
\hline \multirow{2}{*}{$\sigma(\mathrm{C} 2-\mathrm{H} 19)$} & \multirow{2}{*}{1.973} & $\sigma^{*}(\mathrm{C} 1-\mathrm{C} 6)$ & 0.029 & 3.08 & 0.87 & 0.046 \\
\hline & & $\sigma^{*}(\mathrm{C} 3-\mathrm{C} 4)$ & 0.041 & 3.27 & 0.85 & 0.047 \\
\hline$\sigma(\mathrm{C} 3-\mathrm{H} 20)$ & 1.978 & $\sigma^{*}(\mathrm{C} 1-\mathrm{C} 2)$ & 0.070 & 3.24 & 0.86 & 0.048 \\
\hline $\mathrm{LP}(2) \mathrm{O} 7$ & 1.947 & $\pi^{*}(\mathrm{C} 1-\mathrm{C} 2)$ & 0.070 & 8.65 & 0.63 & 0.066 \\
\hline $\mathrm{LP}(1) \mathrm{O} 7$ & 1.976 & $\mathrm{RY}^{*}(1) \mathrm{C} 1$ & 0.008 & 4.29 & 1.52 & 0.072 \\
\hline $\mathrm{LP}(2) \mathrm{O} 7$ & 1.947 & $\pi^{*}(\mathrm{C} 1-\mathrm{C} 11)$ & 0.043 & 4.22 & 0.64 & 0.046 \\
\hline $\mathrm{LP}(1) \mathrm{O} 8$ & 1.977 & $\mathrm{RY}^{*}(1) \mathrm{C} 2$ & 0.007 & 3.36 & 1.38 & 0.061 \\
\hline $\mathrm{LP}(2) \mathrm{O} 8$ & 1.946 & $\pi^{*}(\mathrm{C} 1-\mathrm{C} 2)$ & 0.070 & 9.09 & 0.62 & 0.067 \\
\hline $\mathrm{LP}(2) \mathrm{O} 8$ & 1.946 & $\pi^{*}(\mathrm{C} 2-\mathrm{C} 3)$ & 0.015 & 3.86 & 0.63 & 0.044 \\
\hline LP(2)O9 & 1.957 & $\pi^{*}(\mathrm{C} 3-\mathrm{C} 4)$ & 0.042 & 7.40 & 0.67 & 0.063 \\
\hline LP(2)O9 & 1.957 & $\pi^{*}(\mathrm{C} 3-\mathrm{H} 20)$ & 0.026 & 3.72 & 0.76 & 0.048 \\
\hline $\mathrm{LP}(1) \mathrm{O} 10$ & 1.974 & $\mathrm{RY}^{*}(1) \mathrm{C} 4$ & 0.007 & 3.13 & 1.49 & 0.061 \\
\hline LP(1)O10 & 1.974 & $\pi^{*}(\mathrm{C} 4-\mathrm{C} 5)$ & 0.038 & 3.97 & 0.92 & 0.054 \\
\hline $\mathrm{LP}(2) \mathrm{O} 10$ & 1.941 & $\pi^{*}(\mathrm{C} 4-\mathrm{H} 21)$ & 0.034 & 7.65 & 0.77 & 0.069 \\
\hline $\mathrm{LP}(2) \mathrm{O} 10$ & 1.941 & $\pi^{*}(\mathrm{O} 8-\mathrm{H} 26)$ & 0.028 & 7.14 & 0.84 & 0.069 \\
\hline $\mathrm{LP}(2) \mathrm{O} 12$ & 1.965 & $\pi^{*}(\mathrm{C} 11-\mathrm{H} 29)$ & 0.026 & 5.22 & 0.75 & 0.056 \\
\hline $\mathrm{LP}(2) \mathrm{O} 12$ & 1.965 & $\pi^{*}(\mathrm{C} 11-30)$ & 0.027 & 5.50 & 0.77 & 0.058 \\
\hline LP(1)N13 & 1.908 & $\pi^{*}(\mathrm{C} 5-\mathrm{H} 22)$ & 0.032 & 6.31 & 0.76 & 0.063 \\
\hline $\mathrm{LP}(1) \mathrm{N} 13$ & 1.908 & $\pi^{*}(\mathrm{O} 10-\mathrm{H} 28)$ & 0.027 & 4.86 & 0.76 & 0.055 \\
\hline LP(1)N13 & 1.908 & $\pi^{*}(\mathrm{C} 14-\mathrm{C} 15)$ & 0.040 & 3.46 & 0.69 & 0.044 \\
\hline LP(1)N13 & 1.908 & $\pi^{*}(\mathrm{C} 15-\mathrm{H} 35)$ & 0.028 & 4.21 & 0.76 & 0.051 \\
\hline $\mathrm{LP}(2) \mathrm{O} 17$ & 1.948 & $\pi^{*}(\mathrm{C} 15-\mathrm{C} 16)$ & 0.039 & 9.07 & 0.65 & 0.069 \\
\hline $\mathrm{LP}(2) \mathrm{O} 17$ & 1.948 & $\pi^{*}(\mathrm{C} 16-\mathrm{H} 36)$ & 0.028 & 4.43 & 0.72 & 0.051 \\
\hline $\mathrm{LP}(2) \mathrm{O} 18$ & 1.954 & $\pi^{*}(\mathrm{C} 14-\mathrm{H} 34)$ & 0.023 & 4.83 & 0.67 & 0.051 \\
\hline $\mathrm{LP}(2) \mathrm{O} 18$ & 1.954 & $\pi^{*}(\mathrm{C} 15-\mathrm{H} 35)$ & 0.028 & 6.38 & 0.77 & 0.063 \\
\hline
\end{tabular}




\section{5. Electronic properties}

\subsubsection{UV-Visible spectral analysis}

The experimental UV-Visible electronic absorption maxima ( $\lambda \max$ ) of Voglibose recorded in ethanol together with the theoretical results involving the vertical excitation energies, oscillator strength (f) and wavelength at maximum absorption calculated at B3LYP/ 6-31G(d,p) basis set in gas phase and in ethanol solvent are given in Table 4. The experimental UV-Vis spectrum of the title compound is shown in Fig. 5. Due to the Frank-Condon principle, the maximum absorption peak $(\lambda \max )$ in an UV-visible spectrum corresponds to vertical excitation. The B3LYP/6-31G(d,p) calculations (in ethanol) predict two intense electronic transitions at $7.2622 \mathrm{eV}(270.73 \mathrm{~nm})$ with an oscillator strength $\mathrm{f}=0.0014$ and other one $7.5971 \mathrm{eV}(234.44 \mathrm{~nm})$ with an oscillator strength $\mathrm{f}=$ 0.0103, which are in good agreement with the measured experimental data (261 and $227 \mathrm{~nm}$ ).

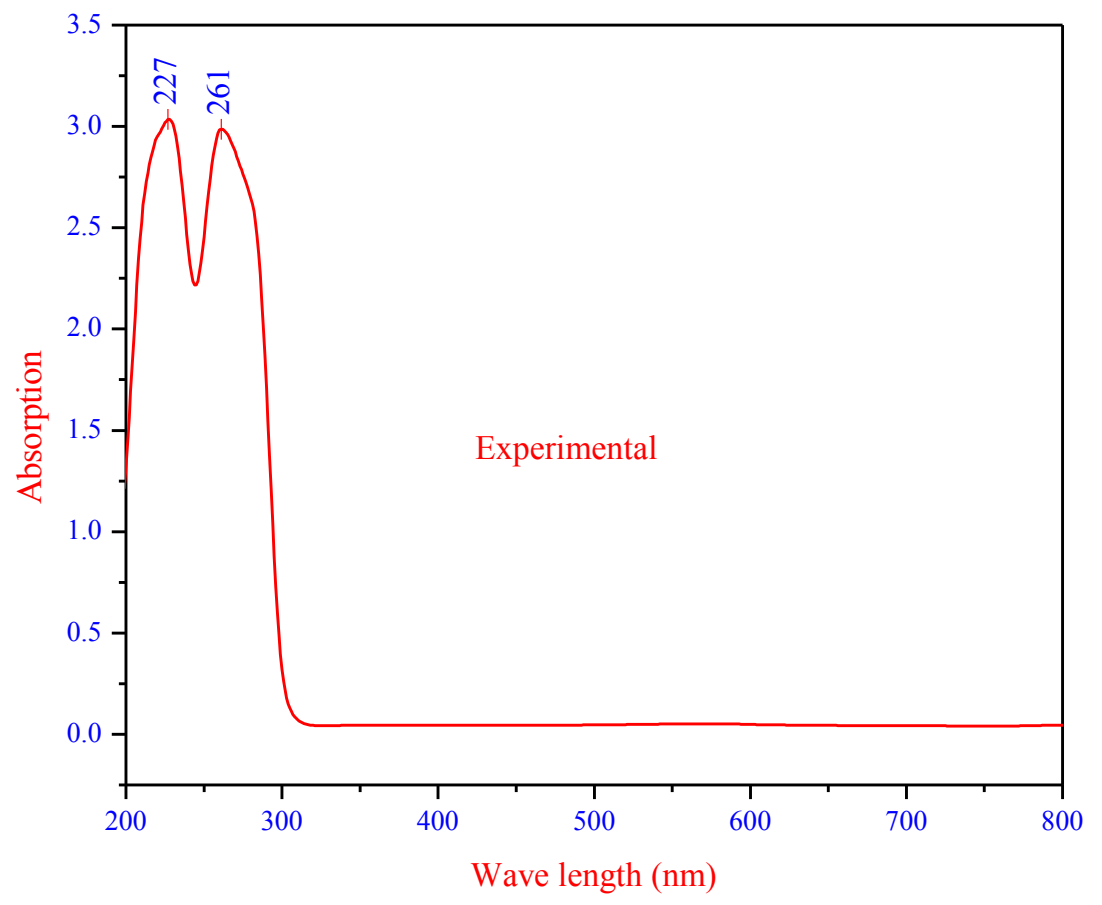

Fig. 5. UV-Visible spectrum (Ethanol) of Voglibose

Table 4. The experimental and computed absorption wavelength $\lambda(\mathrm{nm})$, excitation energies $E(\mathrm{eV})$, absorbance and oscillator strengths $(f)$ of Voglibose in Ethanol solution and gas phase

\begin{tabular}{llllllll}
\hline \multicolumn{2}{c}{ Experimental } & \multicolumn{5}{c}{ TD-DFT/B3LYP/6-31G(d,p) } \\
\hline \multicolumn{3}{c}{ Ethanol } & \multicolumn{5}{c}{ Ethanol } \\
\hline$\lambda(\mathrm{nm})$ & Abs. & $\lambda(\mathrm{nm})$ & $\mathrm{E}(\mathrm{eV})$ & $\mathrm{f}(\mathrm{a} . \mathrm{u})$ & $\lambda(\mathrm{nm})$ & $\mathrm{E}(\mathrm{eV})$ & $\mathrm{f}(\mathrm{a} . \mathrm{u})$ \\
261 & 2.9868 & 270.73 & 7.2622 & 0.0163 & 268.84 & 6.9325 & 0.0014 \\
227 & 3.0363 & 223.20 & 7.5971 & 0.0006 & 234.44 & 7.1077 & 0.0103 \\
- & - & 160.52 & 7.7240 & 0.0404 & 170.09 & 7.2894 & 0.0026 \\
\hline
\end{tabular}

\subsubsection{HOMO-LUMO Analysis}

The highest occupied molecular orbital (HOMO) is the orbital that primarily acts as an electron donor and the lowest unoccupied molecular orbital (LUMO) is the orbital that largely acts as the electron acceptor. The frontier orbital energy gap helps characterize the chemical reactivity 
and kinetic stability of the molecule. According to Fig. 6, the HOMO is spread heavily over the Cyclohexane ring region and LUMO is spread over the entire molecule. For title molecule the calculated HOMO energy is $-6.3460 \mathrm{eV}$ and LUMO energy is $1.1263 \mathrm{eV}$ and the HOMO-LUMO energy gap is $5.2179 \mathrm{eV}$.

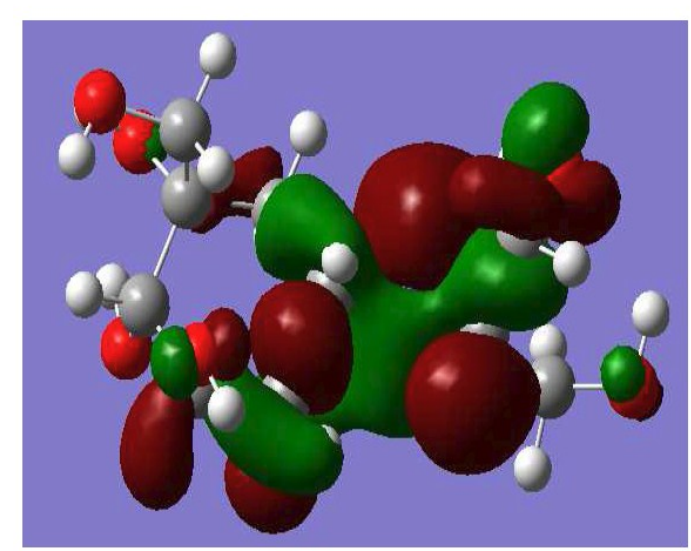

LUMO $=1.1263 \mathrm{eV}$

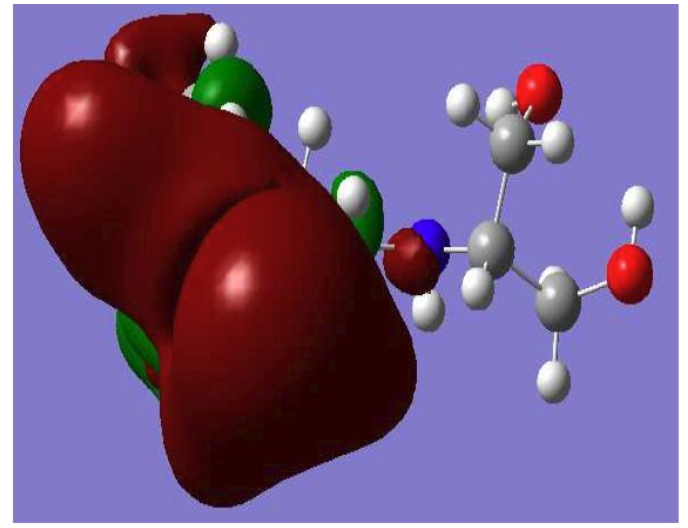

HOMO $=-6.3460 \mathrm{eV}$

Fig.6. The atomic orbital compositions of the frontier molecular orbital for Voglibose

\subsubsection{Molecular Electrostatic Potential (MEP) Analysis}

In order to grasp the molecular interactions, the molecular electrostatic potentials (MEPs) are used. Recently, the MEPs have been used for interpreting and predicting relative reactivities sites for eletrophilic and nucleophilic attack, investigation of biological recognition, hydrogen bonding interactions, studies of molecular cluster, crystal behavior, correlation and prediction of a wide range of macroscopic properties [30]. The MEP diagram (front and back view) of the voglibose molecule is shown in Fig. 7. The color scheme for the MEP surface will be partially negative charge or maybe red-electron rich; partially positive charge or maybe blue-electron deficient; yellow slightly electron packed region; light blue-slightly electron deficient region, Additionally, green color parts represent also regions of zero potential respectively. For the title molecule yellow color represents the electron packed region which is mostly cover the oxygen atoms and also the positive region is actually over the $\mathrm{NH}$ group. Green color represents the zero potential regions mostly over the all protons.

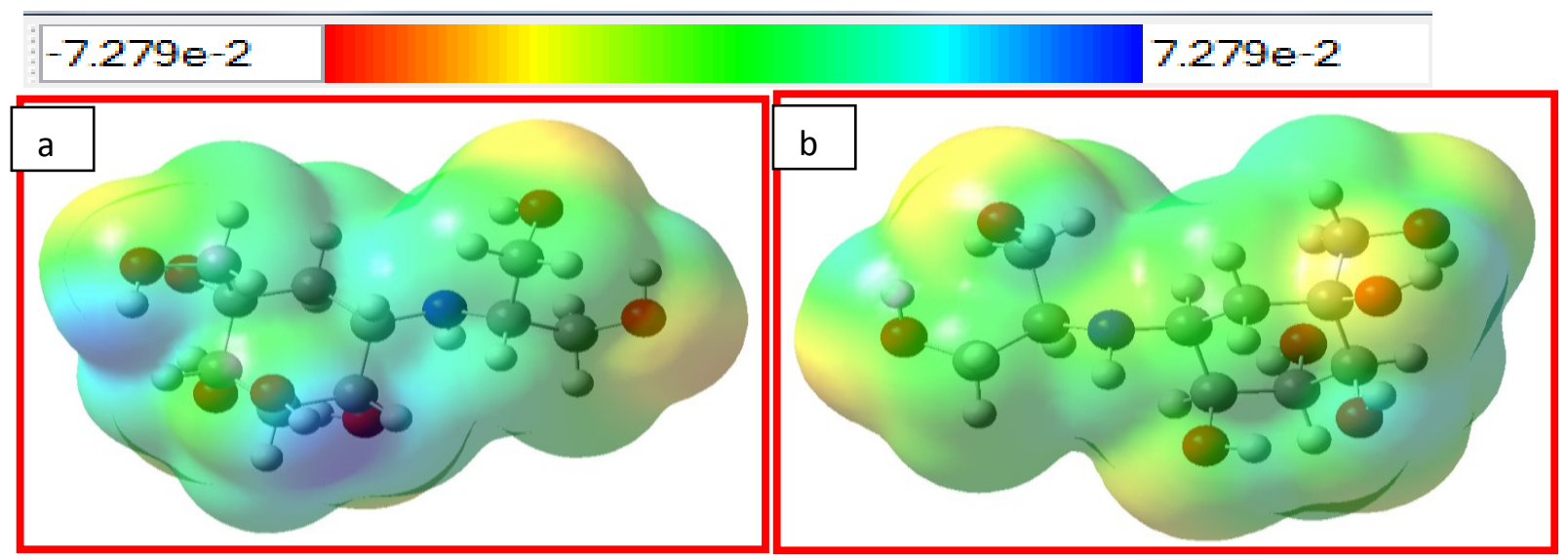

Fig.7. a) Front view b) back view of Molecular electrostatic Potential map (MEP) for Voglibose 


\subsection{NMR spectral Analysis}

NMR spectroscopy has proved to be an exceptional tool to elucidate structure and molecular conformation. The "gauge-independent atomic orbital" (GIAO) method [31] has proven to be quite accepted and accurate, in particular when applied in the context of highly correlated abinitio methods. The ${ }^{1} \mathrm{H}$ and ${ }^{13} \mathrm{C}$ theoretical and experimental [2] (water solvent) chemical shifts, isotropic shielding constants and the assignments of voglibose are also given in the Table 5. Taking into account that the range of ${ }^{13} \mathrm{C}$ NMR chemical shift for analogous organic molecules usually is $>100$ ppm [32]. The chemical shift of $\mathrm{C} 1, \mathrm{C} 2, \mathrm{C} 3, \mathrm{C} 4$ carbon peaks in the rings attached to oxygen atom are observed from $17.10 \mathrm{ppm}$ to $76.28 \mathrm{ppm}$ are calculated from $69.54 \mathrm{ppm}$ to $70.59 \mathrm{ppm}$ at B3LYP/6$31 \mathrm{G}(\mathrm{d}, \mathrm{p})$ level of theory. For title molecule ${ }^{13} \mathrm{C}$ chemical values of these carbon atoms are down shifted from the expected values. The reason for the down shift is due to the substitution of oxygen and carbon atoms for $\mathrm{C} 1$ atom and oxygen and hydrogen atoms for $\mathrm{C} 2, \mathrm{C} 3$, and $\mathrm{C} 4$ atom respectively. Due to the double proton substitution C6 atom get down shifted, the observed / calculated value is $29.34 \mathrm{ppm} / 28.96 \mathrm{ppm}$. Similarly, due to electro negative oxygen atom substitution causes $\mathrm{C} 11, \mathrm{C} 14$ and $\mathrm{C} 16$ atoms gets down shielding shown in Table 5.

Hydrogen attached or nearby electron donating atom or group increases the shielding and moves the resonance towards to a lower frequency. The chemical shifts obtained and calculated for the hydrogen atoms of methyl groups are quite low. All values are $\leq 3 \mathrm{ppm}$ [33] due to shielding effect. In our present study ethylene group chemical shift values of protons H23 and H24 is $1.36 / 1.01,1.89 / 1.48$ (Experimental/calculated). Due to electro negative oxygen bonding causes $\mathrm{H} 25-\mathrm{H} 28$ have the low chemical shift values, which are calculated from 2.29-2.86 ppm by DFT method.

Table 5. Table predicted ${ }^{1} \mathrm{H}$ and ${ }^{13} \mathrm{C}$ NMR isotropic chemical shifts (with respect to TMS, all values in ppm) for Vogliboise

\begin{tabular}{|c|c|c|c|c|c|}
\hline \multicolumn{3}{|c|}{${ }^{13} \mathrm{C}$ NMR } & \multicolumn{3}{|c|}{${ }^{1} \mathrm{H}$ NMR } \\
\hline Atom position & Experimental & B3LYP & Atom position & Experimental & B3LYP \\
\hline $\mathrm{C} 1$ & 74.10 & 69.54 & H19 & 3.67 & 3.69 \\
\hline $\mathrm{C} 2$ & 65.19 & 66.38 & $\mathrm{H} 20$ & & 4.01 \\
\hline $\mathrm{C} 3$ & 72.07 & 67.65 & $\mathrm{H} 21$ & 3.48 & 3.38 \\
\hline $\mathrm{C} 4$ & 76.28 & 70.59 & $\mathrm{H} 22$ & & 2.82 \\
\hline $\mathrm{C} 5$ & - & 50.59 & $\mathrm{H} 23$ & 1.36 & 1.01 \\
\hline C6 & 29.34 & 28.96 & $\mathrm{H} 24$ & 1.89 & 1.48 \\
\hline $\mathrm{C} 11$ & 62.25 & 63.67 & H25 & & 2.29 \\
\hline $\mathrm{C} 14$ & 58.51 & 58.55 & H26 & 2.70 & 2.68 \\
\hline $\mathrm{C} 15$ & 54.46 & 52.83 & H27 & & 0.69 \\
\hline \multirow[t]{12}{*}{$\mathrm{C} 16$} & 56.51 & 56.89 & $\mathrm{H} 28$ & & 2.86 \\
\hline & & & $\mathrm{H} 29$ & 3.23 & 3.21 \\
\hline & & & H30 & & 4.19 \\
\hline & & & H31 & & 0.44 \\
\hline & & & H32 & & -0.29 \\
\hline & & & H33 & 3.56 & 3.57 \\
\hline & & & H34 & 3.25 & 3.31 \\
\hline & & & H35 & & 2.61 \\
\hline & & & H36 & & 3.17 \\
\hline & & & H37 & 3.35 & 3.39 \\
\hline & & & H38 & & 2.61 \\
\hline & & & H39 & & 3.17 \\
\hline
\end{tabular}




\section{Conclusion}

The optimized molecular structure, vibrational frequencies and corresponding vibrational assignments of Voglibose have been calculated using B3LYP level with 6-31G $(\mathrm{d}, \mathrm{p})$ basis set. Considering that experimental and the theoretical studies are performed in different phase, it can be said that there is a good agreement between the experimental and theoretical data. The reduction of $\mathrm{N}-\mathrm{H}$ stretching wavenumber is attributed to the $\mathrm{N}-\mathrm{H}$... O hydrogen bonding interactions. NBO analysis clearly explains the formation of weak $\mathrm{H}$ bonded interaction between the LP(1)N13 and $\pi^{*}(\mathrm{O} 10-\mathrm{H} 28)$ antibonding orbitals and charge transfer causing stabilization of energy $4.86 \mathrm{KJmol}^{-1}$ the system. The energies of important MOs and the max of the compound were also evaluated from TD-DFT method. The ${ }^{13} \mathrm{C}$ and ${ }^{1} \mathrm{H}$ NMR chemical shifts calculated by B3LYP/6-31G(d,p) are closer to the experimental values. Moreover, frontier molecular orbitals and molecular electrostatic potential were visualized. Electronic transition and energy band gap of the title molecule were investigated and interpreted.

\section{References}

[1] N.Mallikarjuna Rao, Konda Ravi Kuma, J. Bagyalakshmi, T.K. Ravi, Ramakotaiah Mogili., "RP-HPLC method development and validation for estimation of Voglibose in bulk and tablet dosage forms" Int. J. Res. Pharm. Sci. Vol-1, Issue-2, (2010), 190-194.

[2] Zhang, C.R. Sun, O. Ishurd, Y.J. Pan, L.S. Ding, "Determination of the structures of four new isomeric cyclitols" Carbo-hydr. Res. 339 (2004) 2027-2030.

[3] X. Chen, Y. Zheng, Y.Shen, Curr. "Voglibose (Basen ${ }^{\circledR}$, AO-128), one of the most important $\alpha$-glucosidase inhibitors", Med. Chem. 13 (2006) 109-116.

[4] Y. Iwamoto, A. Kashiwagi, N. Yamada, S. Terao, N. Mimori, M. Suzuki \& H. Tachibana, "Efficacy and safety of vildagliptin and voglibose in Japanese patients with type 2 diabetes: a 12-week, randomized, double-blind, active-controlled study", Diabetes, Obesity and Metabolism 12, (2010), 700-708.

[5] Karunanidhi Lakshmi and Tirumala Rajesh, "Determination of voglibose in pharmaceutical formulations by high performance liquid chromatography using refractive index detection" European Journal of Chemistry 1 (4) (2010) 262-265.

[6] P. Revathi, T. Jeyaseelan Senthinath, K. Prakash Shyam, A Comparative Study of Acarbose and Voglibose on Postprandial Hyperglycemia and serum lipids in Type 2 Diabetic patients" Int J Med Res. 1(2), (2011) 121-129.

[7] Gaussian 03 program, (Gaussian Inc, Wallingford CT), 2004.

[8] National Institute of Standards and Technology. Vibrational Frequency Scaling Factors on the Web. <http://srdata.nist.gov/cccbdb/vsf.asp> (accessed 24.09.07).

[9] S.M. Islam, S.D. Huelin, M. Dawe, R.A. Poirier, "Comparison of the Standard 6-31G and Binning-Curtiss Basis Sets for Third Row Elements”, J. Chem. Theory Comput. 4 (2008) $86-100$.

[10] M.H. Jamroz "Vibrational Enegy Distribution Analysis", VEDA 4 Computer Program", Poland, (2004).

[11] E.D. Glendening, A.E. Reed, J.E. Carpenter, F. Weinhold, "NBO Version 3.1", TCI, University of Wisconsin, Madison, (1998).

[12] R.Ditchfield, "Molecular orbital theory of magnetic shielding and magnetic susceptibility", J. Chem. Phys. 56 (1972) 5688-5691. 
[13] G. Kereztury, in: J.M. Chalmers, P.R. Griffith (Eds.), "Raman Spectroscopy: Theory, in Hand book of Vibrational Spectroscopy", vol. 1, John Wiley \& Sons Ltd, New York, (2002).

[14] L.E. Sutton, “Tables of Interatomic Distances, Chemical Society”, London, 1958.

[15] K. Govindarasu, E. Kavitha, "Vibrational spectra, molecular structure, NBO, NMR, UV, first order hyperpolarizability, analysis of (S)-(-)-N-(5-Nitro-2-pyridyl) alaninol by Density functional theory" Spectro.chim Acta A 127 (2014) 498-510.

[16] Hong Zhang, Wei-Fen Li, Kui-Wu Wang and Yuan Jiang Pan, "1 Cyclohexylmethoxymethyl-5-[2-hydroxy-1-(hydroxymethyl) ethylamino] cyclohexane-1, 2, 3, 4-tetraol” Acta Cryst. (2004). E60, o299-o300.

[17] J.F. Chiang, S.H. Bauer, "Molecular structure of cyclohexene", J. Am. Chem. Soc. 91 (8) (1969) 1898-1901.

[18] N.H. Andersen , C. J. Nielsen , P.Klaeboe , G.A. Guirgis , J. S. Overby ,S.M. Askarian, "Infrared and Raman spectra, DFT-calculations and spectral assignments of 1,3,5trisilacyclohexane” J. Mol. Struct. 1076 (2014) 419-425.

[19] G.A. Guirgis, H.W. Dukes, J.K. Wyatt, C.J. Nielsen, A. Horn ,V. Aleksa P.Klaeboe "Vibrational spectra, quantum chemical calculations and spectral assignments of 1,1difluoro-1-silacyclohexane" Spectro chim. Acta A 136 (2015) 51-57.

[20] G.A. Guirgis, J.K. Wyatt, C.J. Nielsen, A. Horn ,V. Aleksa P.Klaeboe,' "Infrared and Raman spectra, DFT-calculations and spectral assignments of silacyclohexane" J. Mol. Struct. 1023 (2012) 189-196.

[21] G.Varsanyi, “Assignments for Vibrational Spectra of Seven Hundred Benzene Derivatives", vol. 1-2, Academic Kiaclo, Budapet, (1973).

[22] M. Govindarajan, S. Periyandy, K. Carthigayen, "FT-IR and FT-Raman spectra, thermo dynamical behavior, HOMO and LUMO, UV, NLO properties, computed frequency estimation analysis and electronic structure calculations on $\alpha$-bromotoluene" Spectrochim. Acta 97 (2012) 411-422.

[23] V. Krishnakumar, M. Kumar, N. Prabavathi, R. Mathammal, "Molecular structure, spectroscopic studies (FTIR, FT-Raman and NMR) and HOMO-LUMO analysis of 6chloro-o-cresol and 4-chloro-3-methyl phenol by density functional theory" Spectrochim. Acta A97 (2012) 144-154.

[24] D. Sajan, J. Binoy, B. Pradeep, K.V. Krishnan, V.B. Kartha, I.H. Joe, V.S. Jayakumar, "NIR-FT Raman and infrared spectra and ab initio computations of glycinium oxalate" Spectrochim. Acta A60 (2004) 173.

[25] N.B.Colthup, L.H.Daly, S.E.Wiberly, "Introduction to Infrared and Raman Spectroscopy", 3rd ed., Academic Press, Boston (1990).

[26] R.M.Silverstein, G.C. Bassler, T.C.Morril, "Spectrometric Identification of Organic Compounds", ed. 5, John Wiley and Sons, Inc., Singapore (1991).

[27] K. Govindarasu, E. Kavitha, "Structural, vibrational spectroscopic studies and quantum chemicalcalculations of n-(2,4-dinitrophenyl)-L-alanine methyl ester by density functional theory" J. Mol. Struct. 1088 (2015) 70-84.

[28] M. Jag, "Organic Spectroscopy-Principles and Application', second ed., Narosa Publishing House, New Delhi, (2001).

[29] A.E. Reed, L.A. Curtiss, F. Weinhold, "Intermolecular Interactions from a Natural Bond Orbital, Donor-Acceptor Viewpoint," Chem. Rev. 88 (1988) 899-926. 
[30] J.S. Murray, K.Sen, "Molecular Electrostatic Potential Concepts and Applications, Elsevier Science" B.V, Amsterdaam, The Netherlands (1996).

[31] P.V.R. Schleyer, N.L. Allinger, T. Clark, J. Gasteiger, P.A. Kolmann, H.F. Schaefer, P.R. Schreiner, "The Encyclopedia of Computational Chemistry", John Wiley and Sons, Chichester, (1998).

[32] H.O. Kalinowski, S. Berger, S. Braun, "Carbon-13 NMR Spectroscopy”, John Wiley \& Sons, Chichester, (1988).

[33] F.A. Cotton, C.W. Wilkinson, "Advanced Inorganic Chemistry", 3rd ed., Interscience publisher, New York, (1972). 